Lucía Díaz-Iglesias Llanos

\title{
Products of the Same Master Copy
}

\author{
Deification of Body Limbs in Book of the Dead Spell 42 in TT 11 and pHanover KM 1970.37
}

https://doi.org/10.1515/zaes-2018-0002

Summary: The so-called Gliedervergottung section of BD 42 displays close textual and iconographic features in two Eighteenth Dynasty sources: the burial chamber of the tomb of Djehuty (TT 11) and the papyrus of Baksu (Hanover KM 1970.37). Both sources will be presented, transcribed, and compared to highlight their derivation from the same master copy. Finally, some thoughts on what dublettes can tell us about Book of the Dead Vorlagen and scribal activities will be offered.

Keywords: TT 11 - Hanover Kestner-Museum 1970.37 Book of the Dead - spell BD 42 - master-copy - scribes

\section{Sources}

\subsection{TT 11}

The tomb-chapel of Djehuty (TT 11) has yielded one of the largest and earliest collections of Book of the Dead henceforth BD - spells inscribed on the walls and ceiling of a burial chamber of the early Eighteenth Dynasty ${ }^{1}$. The monument was built around $1470 \mathrm{BC}$, during the joint reign of Hatshepsut-Thutmose III, in the foothill of Dra Abu el-Naga North. It belonged to an individual who held significant positions in the administration as overseer of the royal treasury, overseer of works for royal monuments, as well as overseer of the cattle of Amun. From the innermost room of his funerary monument a shaft $8.20 \mathrm{~m}$ deep leads to the subterranean structures: an antechamber, a second shaft, and the burial chamber. The latter seems not to have fulfilled its mortuary function; the lack of human remains and funerary objects indicates that it was not used as the final resting place for Djehuty, whose disappearance from the political scene by year 17 or 20 of the coregency is still clothed in mystery. The room was (re)

1 Details on the conception, decoration, and transformation of this funerary space are developed in Galán 2012, 2013a, 2013b, 2014 and Díaz-Iglesias 2017.

Lucía Díaz-Iglesias Llanos: email: lucia.diaz-iglesias@cchs.csic.es discovered in 2009 by the Spanish Mission working in TT 11 and 12 under the direction of José M. Galán, after it had been inspected more than a century before by P.E. Newberry ${ }^{2}$. The latter's field notes were never published, nor have they been retrieved in any of the institutions where he worked or to which his widow donated his legacy. The critical edition of the funerary texts will be the object of a forthcoming monograph combining "traditional" and "New" philological approaches, which will shed new light on this extraordinary source for the study of the Theban Book of the Dead recension.

Djehuty's burial chamber included a vast textual and iconographic programme, comprising more than 41 formulae from this corpus, a number that surpassed the collection of spells attested in the tombs of his colleagues Senenmut (TT 353), Amenemhat (TT 82), and Nakhtmin (TT 87) $)^{3}$. Originally, more texts were integrated in the decoration of this room in TT 11, but two of its inscribed walls were hacked up in antiquity in order to enlarge the space, resulting in the partial destruction of their texts and vignettes. In its components and distribution, the decorative programme of Djehuty's burial chamber harked back to the sequence of spells attested on shrouds and papyri of the late Seventeenth Dynasty and early Eighteenth Dynasty, many of which belonged to members of the royal family. The analysis of this chamber indicates that there was a cluster of spells transmitted - in several versions - as a coherent group and transferred to various media (including papyri, shrouds, or tomb walls). But different media and surfaces hosting the same compositions contributed to the creation of new meanings and associations by means of their spatial organisation. For example, against two-dimensional objects, the architectural three-dimensional space of the burial chamber allowed for a more meaningful distribution of the contents: texts concerning the landscape of the Beyond occupied the lower parts of the walls,

2 Galán 2009 provides information on the activities of Spiegelberg and Newberry during their field season at Dra Abu el-Naga in 1899, while the material culture retrieved during the excavation process of the Spanish Mission is presented in Galán 2012, 418-422 and 2014, 252-255.

3 A comparison of the funerary spells included in the few decorated burial chambers of the early Eighteenth Dynasty can be found in Galán 2014, Table 11.2. 
while the ceiling was decorated with sky-related images (the goddess Nut) and compositions, and the entrance was protected with spells against inimical forces.

The texts were copied in columns of cursive hieroglyphs, frequently interspersed with hieratic signs, following a retrograde orientation, and combining the use of red and black inks. They were distributed in several registers (two on the walls and five on the ceiling), and vignettes accompanied some compositions, giving a pictorial rendering of the main purpose of, or an aspect described in, the spell.

Chapter BD 42 was the first text inscribed on the first register of the ceiling. It lacks a title and introductory section, and thus starts directly with the part dedicated to the deification of the deceased's body limbs, the socalled Gliedervergottung ${ }^{4}$. It is highly conspicuous among the surrounding compositions on account of the use of rubricised passages (the proclitic particle $j w$ which introduces each statement is written in red) and of enlarged divine determinatives, which visually dominate this area of the ceiling (figure 1). This spell is usually paired with $\mathrm{BD} 41^{5}$. The latter was written on the right/East side of the North (or entrance) wall ${ }^{6}$, but its text was truncated, since the scribe ran out of space to fit the whole content as he reached the corner of the North and East walls and thus the end of the allotted writing surface. It remains probable that a slight mismatch between the initial planning of the decoration and its practical execution resulted in the omission of both the ending part of BD 41 and the beginning of BD 42.

\section{2 pHanover KM 1970.37/pBrocklehurst}

A papyrus currently housed at the August Kestner-Museum in Hanover under the inventory number 1970.37, but formerly in the hands of the Dent-Brocklehurst family at

4 This term refers to the systematic association/identification of human body limbs -descending downwards from the hair to the toes- with gods or with the respective body parts of the named gods. This mechanism of "deification" and body protection exerted by different deities is a common topic in funerary and magical texts and has been analysed by Ranke 1924; Massart 1959; Altenmüller 1977; Assmann and Bommas 2002, 179-188; DuQuesne 2002; and DíazIglesias 2014, 108 (n. 232), 477-484.

5 According to Lapp (1997, 37-38), it forms part of a whole sequence of spells (BD 31-33-34-35-74-45-93-91-41-42-14) found in other documents.

6 The reading sequence of the texts in the burial chamber is as follows: East wall (hacked up in antiquity) $\rightarrow$ South wall (hacked up in antiquity) $\rightarrow$ West wall $\rightarrow$ North wall $\rightarrow$ ceiling (Galán 2014, 264-265 and Table 11.1).
Sudeley Castle (Cheltenham, UK), bears the closest parallel to the Gliedervergottung copied in TT 11. It is also known under the name of pBrocklehurst II and belonged to an individual called Baksu ( $B j k-s w$ ), who held the title of $w a b$-priest of Amenhotep and could have exerted his priestly function in a Theban temple dedicated to the cult of Amenhotep I ${ }^{7}$. While Djehuty belonged to the highest echelons of the officialdom, being in close contact with the pharaoh, and probably possessed a deep knowledge of religious texts ${ }^{8}$, Baksu was a low-ranking priest. The papyrus of the latter is preserved to a length of $3.84 \mathrm{~m}$ and, given that its beginning and ending sections are damaged, it would originally have been larger.

As is often the case with artefacts decorated with Book of the Dead compositions bought in the antiques market, no absolute dates or archaeological contexts are recorded for the manuscript in Hanover. Information on the exact place of acquisition is also meagre; the only secure data is that the papyrus was bought in Egypt in $1883^{9}$. Some research on its former owner may take us a little further on the open issue of its place of origin.

The papyrus was purchased by Miss Marianne Brocklehurst, who travelled through Egypt four times in 1873-4 (meeting Amelia B. Edwards, with whom she established a good friendship, and keeping an unpublished journal with her activities and purchases), 1882-3, 1890-1, and 1895$6^{10}$. One could venture that she acquired the ancient roll in Luxor, given that an entry on the $17^{\text {th }}$ March 1896 in the Guest Book chez Todros, a reputable dealer at the city, records the following: "after 4 visits to Luxor, we have much pleasure in saying that, the antiquities we have indulged in from Todrous Effendi have given us as much pleasure and satisfaction at home as when purchased here, and

7 The papyrus has been published by I. Munro 1995a; bibliographical references can be further found in I. Munro 1988, 294 (Kat. a. 80) and http://totenbuch.awk.nrw.de/objekt/tm134281 (last accessed 10.09.2016). See also P. Munro 1970 and 1973, 312, 313,5.

8 Attested by his religious titles, which bring him in close contact with Hermopolis and other areas of Middle Egypt active in the production and transmission of religious compositions (overseer of priests in Khemenu, great of the five in the temple of Thot, overseer of priests of Hathor, lady of Qus, overseer of priests and governor in the town of Herwer: Galán 2014, 250 and Table 11.3). Also by the decoration of his monument, displaying one of the oldest and well-developed versions of the Opening of the Mouth in the Eighteenth Dynasty (Serrano 2014) and cryptographic hymns which synthesise the religious knowledge of the owner (Diego Espinel 2014). Against this backdrop, Djehuty could have been personally involved in the selection and arrangement of the texts for his funerary chamber, while this is probably not the case with Baksu and his papyrus.

9 Naville 1886, 68 (Ax).

10 Information on Miss Brocklehurst is assembled in David 1980, 1-23 and Dewachter 1982, 551-552. 


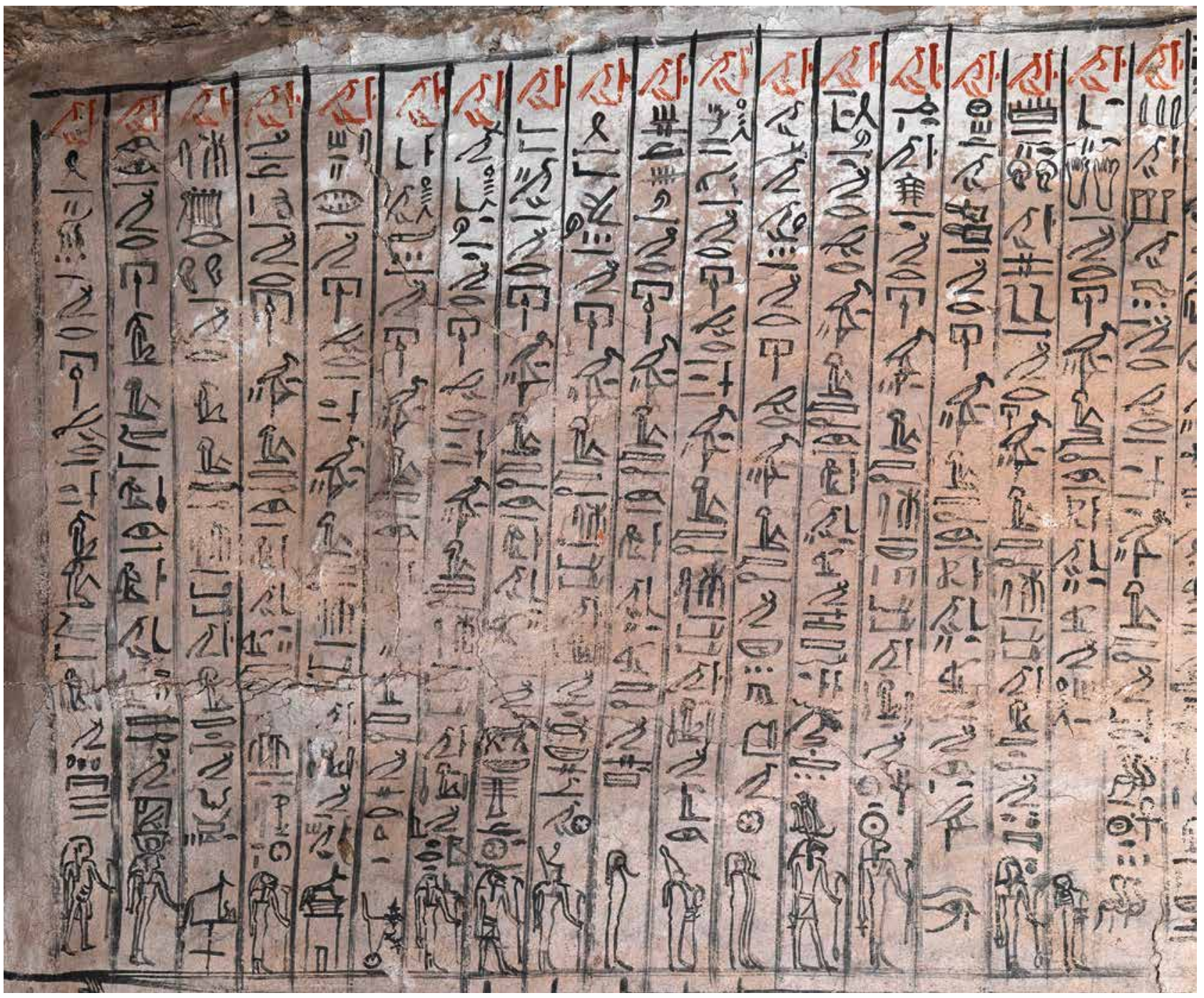

Figure 1: Gliedervergottung on the ceiling of the burial chamber of TT 11. () Djehuty Project.

have all been approved as genuine by Eminent Egyptologists" ${ }^{11}$. This dedicatory statement is certainly no proof of origin, but Miss Marianne Brocklehurst had already acquired another papyrus roll in Luxor ten years before, this time in the West Bank at the Abd er-Rassul's house, ${ }^{12}$ and may well have gone back to this city for her new purchase. Since Luxor was a hot spot for dealers, it is probable that the object had also been retrieved close to this city and not brought there from far away.

Irmtraut Munro tentatively dated this manuscript to the reign of Amenhotep II on account of its similarity to

11 Dewachter 1982, 552.

12 Dewachter 1982, 555-556. It is the so-called pBrocklehurst I, of the Third Intermediate Period, belonging to Djedptahiwefankh, and stemming from the cachette of Deir el-Bahari.
pCairo CG 40002 + pTrieste 12089 a-d (papyrus belonging to Amenhotep) ${ }^{13}$ and to pParis Louvre N. 3074 (papyrus of Tjenena $)^{14}$ in both vignettes' style and motifs and in textual details ${ }^{15}$. This scholar ventures that the manuscripts of

13 I. Munro 1994, 93-126, Photo Pl. 23-45, Pl. 74-99. Further references are available in I. Munro 1988, 275-276 (Kat. a. 10) and http:// totenbuch.awk.nrw.de/objekt/tm133589 (last accessed 10.09.2016). Amenhotep bore the title of $s \check{s}$ hs b mnmnt $n$ Jmn, "scribe of the count of the cattle of Amun".

14 I. Munro 1988, 286 (Kat. a. 48) and http://totenbuch.awk.nrw. de/objekt/tm134307 (last accessed 10.09.2016). Tjenena exerted the functions of $h r(y) m r t n h m t-n t r$, sš, "foreman of the weavers of the god's wife and scribe".

15 pKM 1970.37 and pCairo CG 40002 + pTrieste 12089 are the only witnesses to chapter BD 171, share features in BD 148, and display common 'Austausch-Korrektur-Fehler' in BD 133. The former shares the names of the guardians of BD 144 with pParis Louvre N. 3074. All 
Hanover, Cairo+Trieste, and Paris derived from a common school or were composed using the same master copy and even in the same workshop ${ }^{16}$.

Notwithstanding I. Munro's meticulous analysis of several features in these otherwise undated manuscripts, an earlier date cannot be discarded, especially for pCairo CG 40002. This author initially suggested a wider chronological framework for this papyrus covering the reigns of Thutmose III/Amenhotep II to Amenhotep II, by analysing the figures' formal characteristics ${ }^{17}$. Nonetheless, she later narrowed its dating to the reign of Amenhotep II on account of the representation of a black coffin with yellow bands in the purification and Opening of the Mouth scene. The latter object is, according to the same author, not attested prior to the reign of this king ${ }^{18}$. However, examples of such coffins already exist in the reigns of Hatshepsut and Thutmose III - Cairo JE 66197 (Hatnefer) and Hildesheim 6330 (Amenemope) being the first witnesses to date- ${ }^{19}$ so that I. Munro's earliest suggestion should be kept in mind $^{20}$. As a matter of fact, a date encompassing the reigns of Hatshepsut-Thutmose III and Amenhotep II was also initially posited for pKM 1970.37 by her ${ }^{21}$, but later discarded in favour of Amenhotep II on account of its stylistic similarity with the papyri in Cairo (whose exact adscription to the reign of the latter is not without doubts) and in Paris ${ }^{22}$. Finally, pParis Louvre N. 3074 is also placed by I. Munro in the period of Amenhotep II. Again, an earlier date should not be altogether discarded for this manuscript. I. Munro herself accepted a dating between the reigns of Thutmose III and Amenhotep II on stylistic and iconographic grounds ${ }^{23}$. She favoured the latter however,

three examples exhibit a common style in their vignettes with bagshaped wigs, large eyes reaching the nose, mouths reduced to a line, small bodies with elongated arms and oversized hands. See I. Munro 1988, 134-135, 152, 172-174, 213, 294 and 1995a, 23. P. Munro (1970, 13) also suggests an ‘Entstehungszeit vor Amenophis III’. Luft (1977, 69) posits a date in the reigns of Amenhotep II-Thutmose IV without further explanation.

16 I. Munro 1988, 134-135, 174, 1995a, 27-28.

17 I. Munro 1988, 46-47, 62, 276.

18 I. Munro 1988, 132-133, 276. Another chronological criterion used by I. Munro is the already mentioned closeness in vignettes' style and motifs with pParis Louvre N. 3074 and pKM 1970.37, which she also placed in the reign of Amenhotep II. A similarity in motifs might derive, though, from the use of the same Vorlage.

19 Dodson 1998, 331-332.

20 As the scholar actually does throughout her publication of 1988 (see references quoted in the index before p.135), but not in that of 1994 (93, n. 1), where the possibility of Amenhotep II is favoured.

21 I. Munro 1988, 46 (this wider chronological frame was based on the stylistic-iconographic analysis of its vignettes), 62, 1995a, 28.

22 I. Munro 1988, 135.

23 I. Munro 1988, 6, 47-48, 62, 133. on account of a detail of the burial procession only attested from the reign of Amenhotep II onwards, namely the depiction of a boat on the coffin sledge in the burial procession of chapter BD $1^{24}$. Earlier examples of the insertion of the boat are attested (L. London BM EA 73808) 25 $^{25}$ so that this criterion should not be taken as definite chronological proof.

If chronologically the manuscript in Hanover can be ascribed to a period spanning the reigns of Hatshepsut/ Thutmose III and Amenhotep II, what about its place of production or, at least, of burial? The stylistic connections with the two aforementioned papyri in Cairo and Paris, the title held by Baksu, and the inclusion of spell 171 (so far only attested in the papyrus pCairo CG $40002+$ pTrieste $12089 \mathrm{a}-\mathrm{d}$ ) led Munro also to suggest a Theban origin for pKM $1970.37^{26}$. The place of purchase of this papyrus by Miss Marianne Brocklehurst suggested above, Luxor, could also corroborate Munro's statement. On the whole, the suggestion that Baksu's tomb was located somewhere in the Theban necropoleis might not be too speculative.

The funerary document in Hanover was not composed for Baksu ex-profeso. It was manufactured in advance and the name of the latter was only added in four places $a$ posteriori, leaving the rest of the spaces intended for owner's identification void in the nearly 4 metres of preserved decorated surface. Following the typical layout of New Kingdom Book of the Dead manuscripts, the text was copied in cursive hieroglyphs - in die nur einige wenige hieratisch geprägte Zeichen eingestreut sind'-, in columns, and retrogradely. The same combination of red and black inks as in TT 11 is attested in this papyrus. On the contrary, the enlarged divine determinatives at the bottom of each column of the section of $\mathrm{BD} 42$ bearing the identification of a body limb with a deity are rendered in colour, using red, yellow, green, blue, white, and black.

In contrast to TT 11, BD 42 was not paired in this papyrus with spell 41, but was placed within a sequence of texts revolving around the topics of the solar boat (its reconstruction and the deceased's journey on board) and the adoration of Re: BD 132, 102, 99/99B. Spell 42 lacked a title in this version, starting directly with the introductory section, and finished after all limbs of the deceased were equated with different divinities. The latter is the only textual section of BD 42 shared by the two sources

24 I. Munro 1988, 16-18, 64, 284 (the use of the black coffin as dating criteria in the purification scene has been nuanced above).

25 Taylor (ed.) 2010, 67. Tawfik (2008, 20, 196) considers that the bark was introduced as a fixed element of the Mumientransportzug in the burial procession in the transition between Thutmose III and Amenhotep II, with the earliest exemplars spanning both reigns. 26 I. Munro 1988, 272 and 1995a, 28. See also P. Munro 1970, 13. 
compared here but can give us interesting information on scribal attitudes towards master copies. While this part of the composition was written in one-register columns on the ceiling of TT 11, it adopted a table-like distribution on the scroll pKM 1970.37, with the identifications divided in two superimposed registers (figure 2). The difference affects only the external layout, given that both examples are practically identical in inner textual and iconographic details as will be pointed out in section 3 .

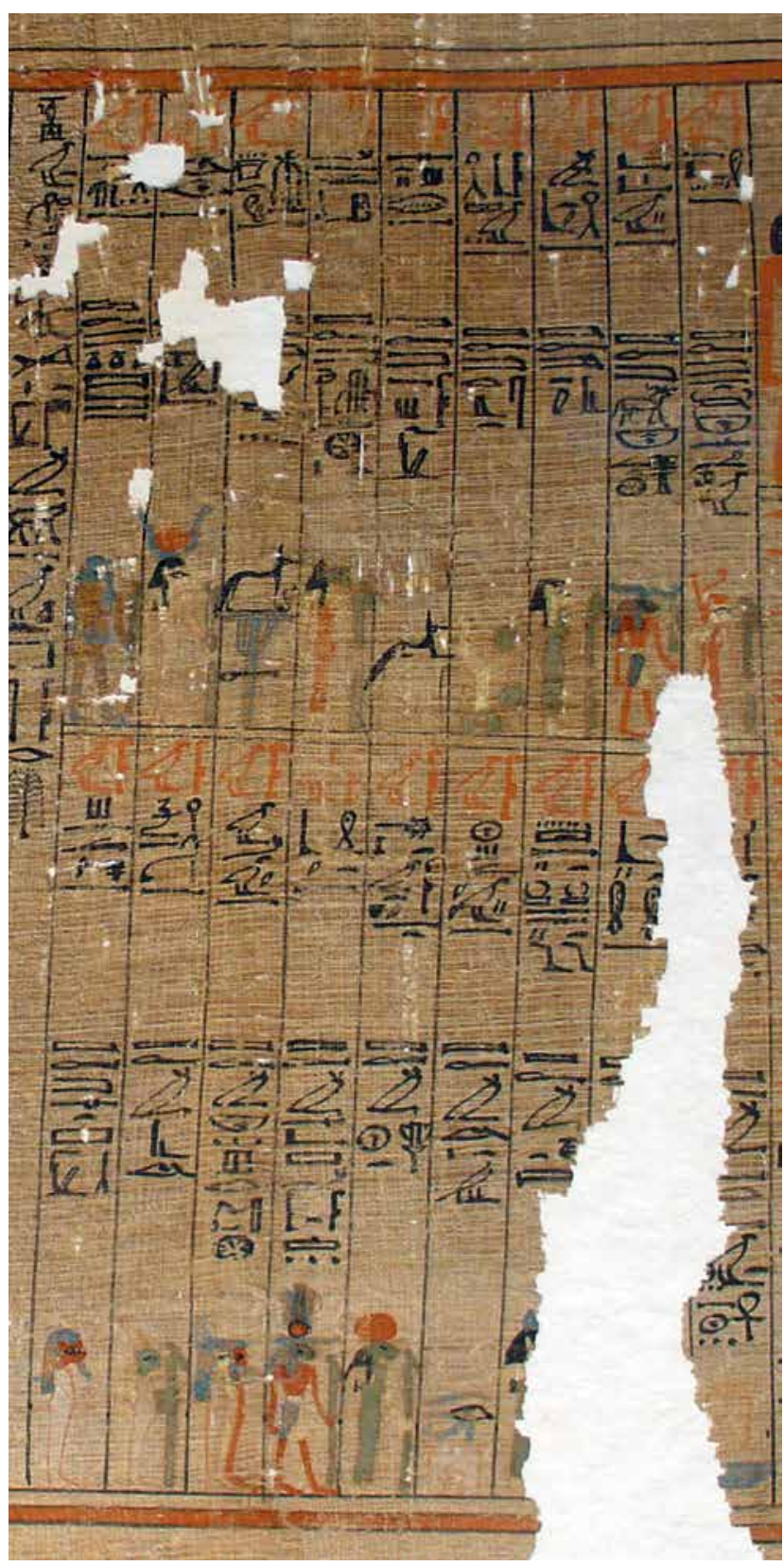

Figure 2: Gliedervergottung in pKM 1970.37. ( ) August KestnerMuseum, Hanover. Photographers: G. Lapp/B. Lüscher

\section{Spell BD 42, Gliedervergottung}

BD 42 is a composition included in the group of spells destined to repel hostile forces ${ }^{27}$. Its title, "Formula for repelling the slaughter that is done in Herakleopolis Magna", recalls the mytheme of the rebellion and annihilation of human beings ${ }^{28}$, while the content is centred on the identification of body parts with deities and the self-presentation of the deceased as a solar divine entity, protected against any peril and entitled to several benefits in the hereafter. Specifically, the Gliedervergottung -or alignment of body parts with gods- is a magical device recorded in earlier sources ${ }^{29}$ intended to promote the deification of the deceased, reassemble his/her dispersed limbs and thus secure the integrity of the physical component for the afterlife, and achieve his/her integration in the protective sphere of the gods. This device is mobilised both in medical and magical compositions, to cure diseases or prevent the sting of venomous creatures ${ }^{30}$, and in funerary texts, perhaps originally stemming from the embalming ritual. It is interesting to note that neither the order in which the body limbs are listed, nor the equivalences established between the single limbs and specific deities remain constant (though they tend to recur) in different versions of the same spell ${ }^{31}$, and that the number of discrepancies in the equivalences increases when different compositions are compared.

The pictorial component of BD 42 in New Kingdom productions can be of two types, although these are not attested in all examples ${ }^{32}$ :

1) a vignette related to the title of the spell, either representing the act of repelling the sign of slaughter or a snake, or based on an iconographic pun of the name of Herakleopolis Magna or its main religious figure, Heryshef;

27 Lapp 2017 includes a synoptical edition of chapters BD 31-42 in New Kingdom manuscripts. Bibliography on this spell is collected in Backes et al. 2009, 139-140.

28 For the title $r n h s f \breve{s} c_{t}$ jrrt $m N n$-nsw, its variants, and the episodes of destruction of humanity framed in the city of $N n$ - nsw, see Backes 2010b and Díaz-Iglesias Llanos 2014, 149-170.

29 A precursor of the whole sequence of identifications running from head to feet in BD 42 can be found in CT VI, $391 \mathrm{i}-392 \mathrm{~d}$ [761]. For bibliographical references to the Gliedervergottung, see n. 4 above.

30 Quirke $(2013,121)$ suggests that BD 42 could derive from Middle Kingdom health incantations for repelling harmful forces.

31 For BD 42, see I. Munro 1988, 168-172, 224-231 (Liste 10, New Kingdom sources) and Díaz-Iglesias Llanos 2014, 478-484 (sources from the New Kingdom through the Ptolemaic Period).

32 According to I. Munro 1988, 74-76, Milde 1991, 224-226 and Tarasenko 2009, 246-264 and 2013, 329-333. 
2) emphasis on the Gliedervergottung section through its insertion within a table ${ }^{33}$ or chapel-like structure. Against a running text, which is attested contemporaneously for example in pLondon BM EA $10477^{34}$, the mixture of table and list format (with each equation occupying one column) resulted in a powerful visual and spatial ordering of the contents ${ }^{35}$. This enumeration could be further written as a continuous block (one column after the other in a single register) or be divided into two or several registers, one on top of the other. Another way of aesthetically highlighting this section is by rendering detailed (quasi vignette-like) divine determinatives after the gods' names at the bottom of each column. TT 11 and pKM 1970.37 have in common the omission of the generic divine determinative (A40 요) in each deity's names, the spatial separation of the phonetic components from the specific determinative ${ }^{36}$, and the rendering of the latter as oversized figures $^{37}$.

\section{Products of the same master copy}

According to I. Munro, the papyri pParis Louvre N. 3074 (Tjenena, figure 3) and pKM 1970.37 (Baksu, figure 2) shared a common Vorlage in the section dedicated to the deification of the body limbs in spell BD 42. Her observation was mainly based on the "Übereinstimmung in der Gestaltung der vignettenartig wiedergegebenen Götterdeterminative in $\mathrm{Tb} 42^{\prime 38}$. However, there are several differ-

33 Such a procedure is also mobilised in the table-like sections of other BD spells (99, 125, and 141/142).

34 Lapp 1997, Pls. 16-17.

35 The purpose and meaning of lists in ancient Egypt is recently explored by several authors in Deicher and Maroko 2015. For the categories of enumerations, lists, tables, and catalogues in all types of sources and their interrelation, see the contribution of Hoffmann 2015.

36 The separation of determinatives from Lautkörper in words is a device often attested in lists, which facilitates the conversion of lists into tables (Hoffmann 2015, 93-94).

37 In the Litany of Re the same possibilities of laying the contents are also attested: as a running text, with each invocation occupying a column in a table, and with the epithets of the sun god rendered with oversized determinatives separated from the phonetic parts of the epithets (Hoffmann 2015, 96-99).

38 I. Munro 1988, 168. See also l.c. and 75-76, 134 where she highlights that both manuscripts share her so-called model C in the Gliedervergottung and 1995a, 27. Such a common Vorlage was also suggested by this same author for other vignettes included in both papyri (1988, 70, 134), but many others also differ in their underlying model. ences between these two witnesses in various iconographic and textual details that preclude the use of the same master copy (or at least would entail the combination with another Vorlage to produce the version copied in the first of them). On the other hand, exact equivalences can be found between the version of this deification section in the Hanover papyrus and that of TT 11, unknown at the time when I. Munro published her study, in the number of limbs identified with gods, grammatical structures, orthography of words, and formal features of the divine determinatives. These similarities, reviewed in detail below, are so strong that they can most plausibly be explained if a common master copy was used to produce both.

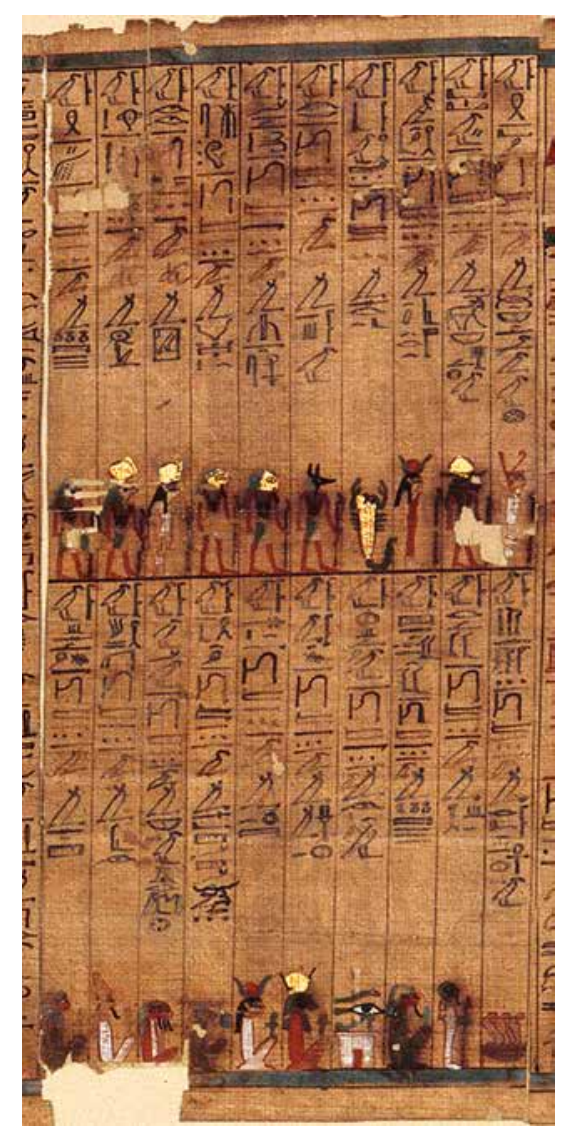

Figure 3: Gliedervergottung in pParis Louvre N. 3074. (c) Musée du Louvre/Georges Poncet.

The enlarged determinatives, i.e. the basic factor upon which I. Munro postulated a common Vorlage for the manuscripts of Baksu and Tjenena, differ in at least 6 aspects on closer inspection of both versions:

1) the nudeness and fecundity-figure-like body of Nun in pKM 1970.37 contrasts to his being clad in a kilt in pParis Louvre N. 3074; 
2) the full zoomorphic appearance of Wepwawet and Anubis in the former differs from the latter's preference for the anthropomorphic and mixed -canine head and human body- forms of these deities;

3) the feminine treatment of the divinity Hnty-h 3 s in the Hanover papyrus stands in opposition to its rendering as a male god in the manuscript of Tjenena ${ }^{39}$;

4) the items of regalia of several divine figures, mainly the crowns worn by the $c 3$ šfyt and Sekhmet and the headdress of Isis, also differ between both examples;

5) the appearance of Serket displays notorious differences: while she is represented as the poisonous terrestrial scorpion in the manuscript of Paris, she is depicted as the innocuous water bug ('nèpe, scorpion d'eau') in that of Hanover ${ }^{40}$;

6) disparities are more prominent in the lower registers of the table: while the deities are depicted standing in the manuscript of Hanover, most of them are squatting in that kept at the Louvre. A different attitude is accompanied by changes in the attributes held in the hands; the long staves and scepters of pKM 1970.37 contrast with the shorter staves or by the ankh-signs, both of which better suited the squatting position.

Notwithstanding the similarities between the manuscripts of Tjenena and Baksu in the general layout ${ }^{41}$, grammatical constructions, and orthography, they also display notorious textual differences ${ }^{42}$. The former unfolds the Gliedervergottung in 20 identifications, adding the face (aligned with $\mathrm{Re}$ ) and subdividing the belly- $\underline{h} t$ and the spine-j3t (coupled with Sekhmet in the latter) into two di-

39 In other instances, it is also accompanied by a male determinative (A40), such as in pParis Louvre E. 11085 (I. Munro 1995b, Photo-Pl. 10, col. 200). For this deity, documented in the New Kingdom as a lion-faced goddess, associated with Bastet and Sekhmet, see $L G G \mathrm{~V}$, 923 (Die Vorsteherin von $\mathrm{H} 3 \mathrm{~s}$ ).

40 For the different visual renderings of the goddess and her main attributes in the realms of birth and rebirth, see Spieser 2001 and 2006. The author highlights the predominance of the scorpion iconography from the New Kingdom onwards. The appearance of Serket in pKM 1970.70 and TT 11 is the same, mixing the water-bug form with the scorpion tail, although ankh-signs have been added to the pincers of the insect in the latter (for parallels and the meaning of such signs, see Spieser 2001, 260).

41 Both papyri display the Gliedervergottung according to subtype B1 - tables of vignettes divided into two registers - in the classification of Tarasenko $(2013,330)$.

42 This trait was also noted by I. Munro, who stated: "verwirrt zunächst die Diskrepanz der zugehörigen Texte der drei Hss. (i.e. the papyri of Amenhotep, Tjenena, and Baksu) unter einander" (1988, 168). Notwithstanding this statement, a textual comparison among the three versions led her to postulate that they were based on a “durchgängiges Grundmuster”. vine associations. Moreover, not all correlations between body limb and divinity coincide between the two papyri. For example, the thighs and the calves (mnty and ssty) are equated with Nut in the case of the Hanover roll, while they are identified with Nun in that of the Louvre. The former associates the tbty-sole of feet with Ptah, while in the latter the $r d w y$-feet are set in relation with this deity.

Reference was made at the beginning of this section to the strong similarities shared by the variants copied in the papyrus of Baksu and on the ceiling of the burial chamber of Djehuty. Both instances are transcribed and compared below before highlighting their common traits and drawing wider conclusions on scribal activities and Book of the Dead production.

\section{Transcription of the Gliedervergottung in BD 42 in TT 11 (figure 4$)^{43}$}

Notes:

a) Each statement composing the section alternates a reference to Djehuty's father or mother. After writing the paternal filiation ( $j r-n J b w t y)$, the scribe continued copying the maternal one ( $m s-n D d j 3)$. As he reached the end of the column and lacking space to fit the figure of Hathor, he erased the signs composing the maternal filiation and wrote the corresponding identification ( $m H w t-H r w)$ on top of them. This is a clear indication that the divine determinatives were not written before - at the bottom of the columns and the rest of the text inserted later ${ }^{44}$, but that both

43 Due to the scarcity of published manuscripts, other sources used for comparison and quoted in the notes were accessed via http:// totenbuch.awk.nrw.de/. Most of the 26 documents for BD 42 of the Eighteenth Dynasty assembled in this database are in a fragmentary state. Sources used for the comparison, dated between the beginning of the Eighteenth Dynasty until the reign of Thutmose IV, are: pParis Louvre E. 11085 (I. Munro 1995b, Photo-Pl. 10, Pl. 17-18), pBoston MFA 22.401, pLondon BM EA 10477 (Lapp 1997), pLondon BM EA 9964, pParis Louvre N. 3074, pCairo CG 40002 + pTrieste 12089 a-d (I. Munro 1994, 93-126, Photo-Pl. 23-45), pCairo CG 40003 (I. Munro 1994, 127-140, Photo-Pl. 46-53), pParis Louvre N. 3092, pParis Louvre AE/N 3068 (Devéria and Pierret 1872), pParis Louvre N. 3092 (Ratié 1968).

44 Given the treatment of the determinatives as quasi-vignettes (larger in size than normal signs, more detailed in rendering, and filled with colours in the Hanover manuscript), their inclusion could follow one of the production processes attested in some papyri: either, and more frequently, the text was copied first and spaces were left for the vignettes to be drawn by draughtsmen (see pMarseille 291 (Nespasef: Verhoeven 1999, 50, 51, n. 24) and pTurin 1812 (Irtiwrw, http:// totenbuch.awk.nrw.de/objekt/tm57580, last accessed 10.09.2016), where most of the spaces have not been filled with images), or the vignettes were inserted first and the texts surrounded them (pLeiden T2 (Qenena: http://totenbuch.awk.nrw.de/objekt/tm134346, last 
elements were copied at the same time. The parent's names were omitted in columns 1,12 (probably owing to a lapse of the scribe's concentration) and 18 (most likely due to a lack of space).

b) Djehuty's titles are often wrongly spelled in this section of BD 42. The $r$ or the $p r-\underline{h} \underline{d}$ of the title jmy-r pr- $\underline{h} \underline{d}$ are missing in five columns, while in column 16 the latter was added at a secondary stage, written to one side, at a smaller scale, and with fresh ink. One may well see these omissions and the one mentioned under note r) as proof of a work executed in haste. However, defective writings of these common elements of the owner's titles may also be owed to the fact that the surface - the ceiling - or the formulaic nature of the text - repetition of statements with a similar structure and minor variations in content - had a negative effect on the concentration of the scribe. Note also that

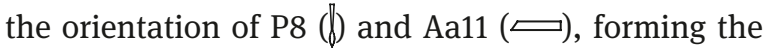
expression $m 3^{3}-h r w$, is often reversed in this part of the chamber, which may also be due to the problems posed to the copyist by the writing surface or the unusual body posture adopted when inscribing on the ceiling. Such straining working conditions and the speed in execution may stand behind the concentration of mistakes, omissions, erasures, and secondary additions in this area (see notes c, f, h, j, k, n, o, p, q, $\mathrm{r}$, and $\mathrm{z})^{45}$.

c) A vertical sign beneath the two Gardiner D37 signs may betray a scribal mistake in the spelling of the name of Djehuty's mother. The copyist seems to have first written a $j$ and then erased it.

d) According to I. Munro (1989, 226 and 1994, 97, n. 1), three variants of the deity referred to in this equation are attested in Eighteenth Dynasty manuscripts: 1) Hnty-h̆js; 2) Hnty-hm, 3), Hnty-šps/špst/špsj. Variant 1) is recorded in TT 11 and in pKM 1970.30 (see note B below).

e) The word is attested in singular (but with a dual determinative), plural, and -most often- in dual (cf. Munro 1994, 97, n. i).

f) Omission of feminine ending in $m 3^{3} t-h r w$.

accessed 10.09.2016) and pParis BN 62-88 (Ankhesenaset: Ragazzoli 2010, 230-232, 234-235)).

45 Mauric-Barberio $(2003,187)$ highlights the different material conditions affecting the work of scribes: "je me demande si l'on peut mettre sur le même plan le travail d'un scribe rédigeant un texte sur papyrus et celui de décorateurs réalisant la mise en place d'une composition sur une paroi, le tout dans les conditions d'éclairage, de chaleur, et de manque d'air, très difficiles". g) The $j b h w$-teeth can be also coupled with Khepri (examples provided by Munro 1988, 126, 226 and 1994, 131, n. e).

h) The end of the statement presents several corrections, probably introduced when the scribe realised that there was not enough space left within which to fit the content: the signs Q1 (』) and R8 ( (), initially written below the preposition $m$, were subsequently washed off. Afterwards, the former was squeezed in after the $m$ and the latter rewritten below it and on top of the half-erased Q1. As a result, the name of Isis was anomalously rendered.

i) The goddesses of columns 7 and 16 look alike, hold the same attributes, and bear no distinctive crown. In order to distinguish them a small hieroglyphic sign was added as a scribal mark beside their heads: Q1 (』) for Isis and W24 (C) for Nut. Alternatively, it is possible that the signs were written to one side and not on top of the goddesses' heads, as one would expect, for lack of space.

j) Under the ${ }^{c}$ a partially erased oblique stroke is visible. Could it be part of the sign Möller II 125? This would mean that the copyist initially altered the signs' positions within the word $\breve{s}^{c}$ and subsequently corrected his mistake.

k) The sign F51 ( $\mathrm{Q}$ ) was written off-centre (cf. its position in the following column complementing the word $p s \underline{d}$ ), probably as a result of its being inserted secondarily, once the plural strokes had been copied.

1) Superfluous plural strokes in the spelling of $\bar{s}^{c}(W b$. IV, 506, 14). They are also attested in the orthography of the same word in pKM 1970.37 (see n. F below) and in pParis Louvre E. 11085 (Munro 1995b, Photo-Pl. 10, col. 201, p. 19, n. j), while the plural mark $-w$ is documented in other roughly contemporary cases (pCairo CG 40002: Munro 1994, Pl. 75, col. 35 and p. 97, n. j). However, these examples constitute the exception rather than the rule.

m) Omission of the feminine ending $-t$ in the epithet of the goddess Neith ( $n b t \breve{S} 3 w)$. The same omission is attested in pKM 1970.37 (see n. G below), pCairo CG 40002 (Munro 1994, Pl. 75, col. 35), and pLondon BM EA 9964.

n) Under the $d$-sign, a diagonal stroke is visible, indicating that the scribe began to write the determinative for backbone before inserting the last phoneme of the word $p s d$. The mistake was corrected along the way, simply juxtaposing the horizontal stroke of the grapheme $d$ over the diagonal one. 
Ceiling, reg. I, cols. 1-18 (BD 42)

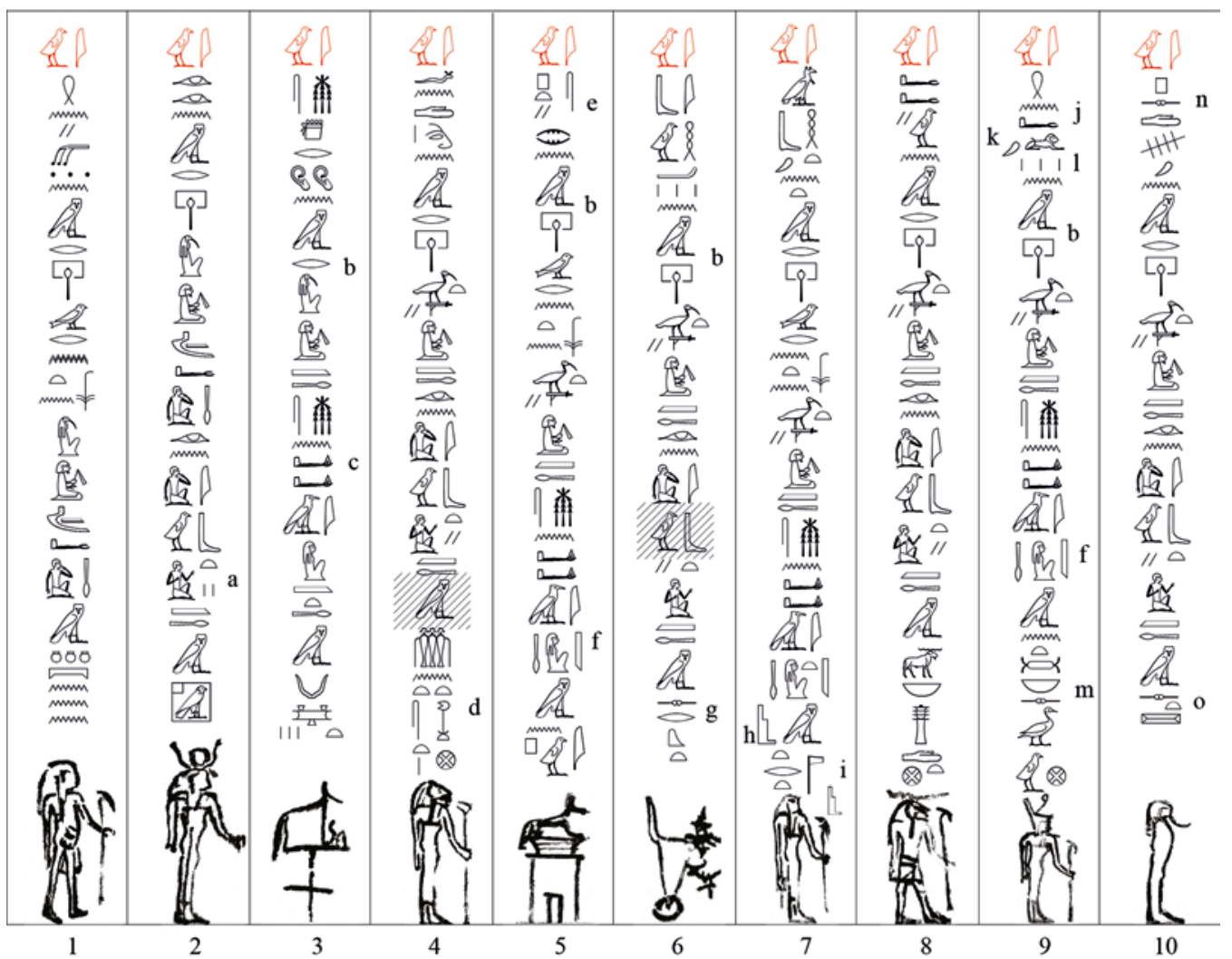

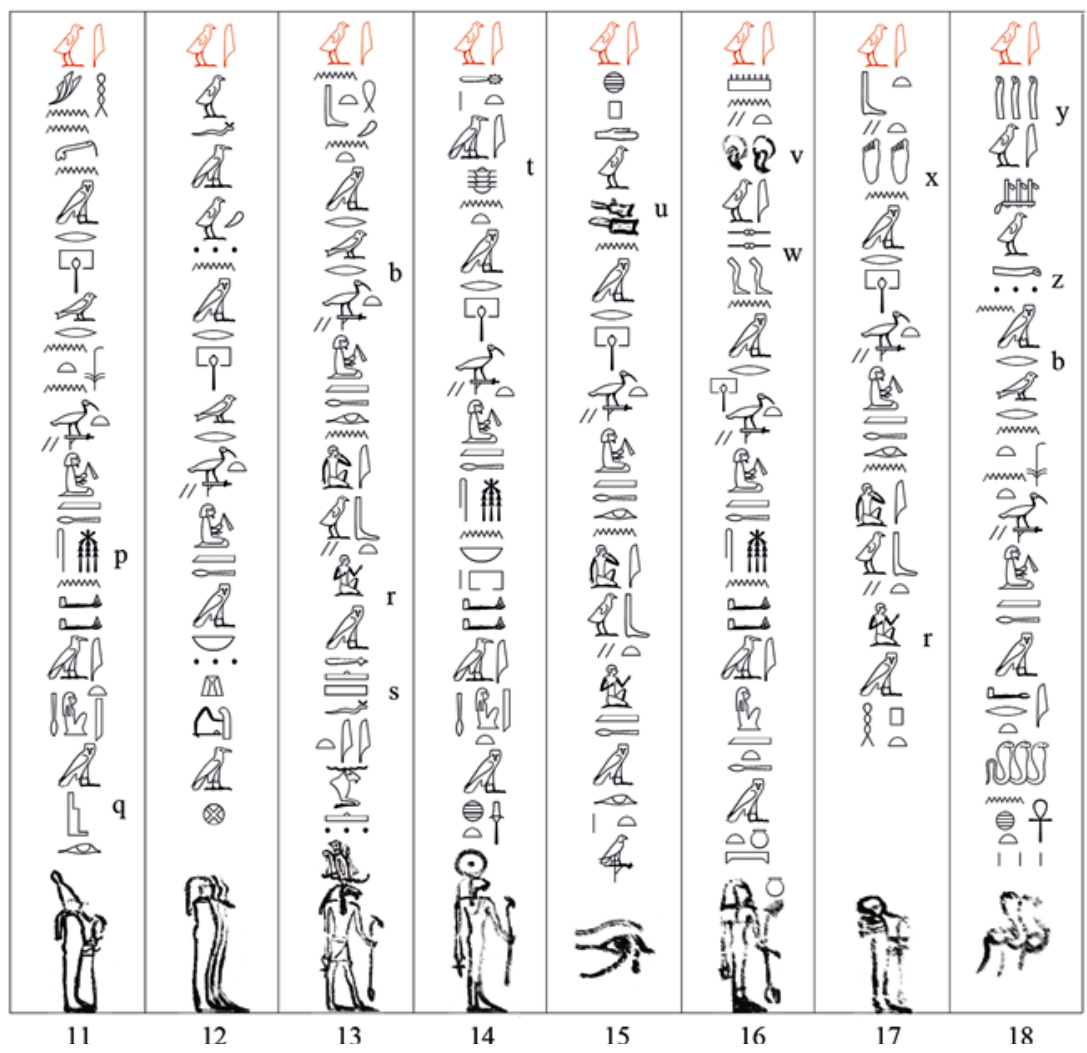

Figure 4: Transcription of the Gliedervergottung in BD 42 in TT 11. 
o) The $t$-sign was added later by the scribe, possibly while looking back at the copied text when refilling the writing tool or when cursorily reading the section.

p) Below the $m s$ and $s$ signs the preposition $m$ is visible. After writing the name of Djehuty, the scribe probably forgot to add the paternal filiation and directly jumped to the adverbial predicate with the $m$ of identity. His mistake was emended.

q) The initial confusion in the signs' positions within the name of Osiris (writing the sign D4 - - before Q1 』-) was quickly corrected by the scribe, who partially erased the upper stroke of D4 and wrote the sign Q1 on top.

r) Omission of $m 3^{\mathcal{C}}$-h $h r w$ after Djehuty's father name.

s) The variant $\check{s} f s f t$ is attested in most of the Eighteenth Dynasty witnesses of BD 42, while the word is written as šfyt in TT 11 and pKM 1970.38.

t) Omission of the feminine ending $-t$ in the word $j 3 t$, spine ( $W b$. I, 26, 3-6). Most parallels opt for the determinative F37 (backbone and ribs, HWh), while TT 11 and pKM 1970.38 display the more elaborate F41 (vertebrae,

u) The word is written in plural (cf. n. L below), but the two ending graphemes point in the direction of a dual form. No parallel could be found for these signs defining the semantic sphere of the term. The word $h p d / h p d w y$, buttock(s), is usually complemented by the following determinatives in other BD sources: (pBoston MFA 22.401), $\bigcirc$ (pLondon BM EA 10477, pLondon BM EA 9964, pCairo CG 40002, pParis Louvre N. 3074, pParis Louvre AE/N 3068), $\bigcirc$ (pParis Louvre E. 11085, pParis Louvre N 3092, pKM 1970.37). Other spellings registered in $W b$. III, 270, 14-271, 3 include the signs:

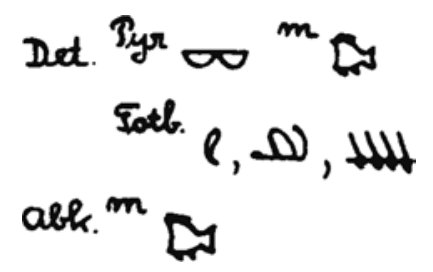

Except for the fish, and only vaguely, none of the attested determinatives resemble what was written on the ceiling of TT 11. One may wonder if in the latter case the sign could derive from a scribal reinterpretation of an unfamiliar grapheme. However, a sign with the same shape reappears in the burial chamber in another spell (BD 149, fifth mound, see figure 6), so that we may be faced with a case of scribal faithful reproduction of the model.

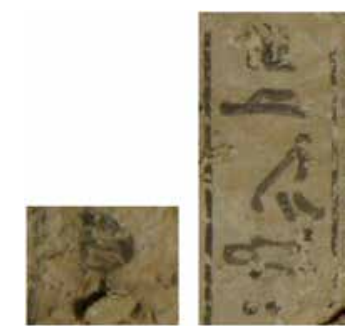

Figure 6: Spelling of the word $h p d w$ in BD 149 in TT 11. (C) Djehuty Project

v) An unusual determinative complements the word mnty. None of the signs recorded in Wb. II, 68, 8-15 come close to the mushroom-like determinative of TT 11.

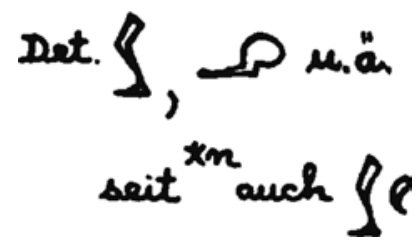

At the light of the anomalous orthography of the same word in pKM 1970.37 (see n. M below), it is conceivable that the master copy bore a round-topped sign and that the scribes struggled to render the unfamiliar grapheme, producing their personal and unique variants.

w) Omission of the $-t$ in the spelling of ssty (also omitted in pCairo CG 40002, Munro 1994, Pl. 75, col. 47).

$\mathrm{x}$ The soles of the feet (tbty) are usually accompanied by the signs of the sandals (Gardiner S33 $\mathrm{R}, \mathrm{Wb} . \mathrm{V}, 361$, 9-363,3) not by the detailed rendering of the soles ( $(0)$, which constitutes quite a unique instance. According to an extended tradition, the $r d w y$ are the body limbs linked to Ptah (see Munro 1988, 230).

y) The fingers $\left(d b^{c} w\right)$ are omitted in most of the versions of BD 42. TT 11, pBoston MFA 22.401, pKM 1970.37, pParis Louvre N. 3074, and pParis Louvre N. 3092, where these are included, represent another minority tradition.

z) The use of the sign D51 (๘) as a determinative for sihw (Wb. IV, 20, 1-4) is, to my knowledge, only attested in TT 11 and pParis Louvre N. 3092. It remains possible that this sign was also used in pKM 1970.37 (column 9, below), but the word is marred by lacunae. Below the plural strokes, the sign of the indirect genitive seems to have been added secondarily in TT 11 .

Transcription of the Gliedervergottung in BD 42 in pKM 1970.37 (figure 5). The transcription offered here differs from that of I. Munro (1995a, Pl. 9) in columns 157 and 158 (lower section), and 161 (upper and lower sections). 
Notes:

A) All spaces left blank at the time of production and intended for inserting the owner's name once the papyrus was bought or ready for use remained void in this section.

B) Name of deity spelled Hnty-hiss, as in TT 11 (see note d above).

C) The names of Anubis and Seth are accompanied by the generic divine determinative A40 ( $\hat{\text { N }}$ ) and followed by their specific enlarged canine and mummiform determinatives. No use of the sign A40 is attested in this section of BD 42 in TT 11.

D) Omission of feminine concordance in the genitival adjective.

E) The epithet ntrt of Isis is commonly written in the parallels (I. Munro 1988, 227). If recorded in the master copy, no space constraints on the writing surface would explain its omission in pKM 1970.37.

F) Superfluous plural strokes in the orthography of $\check{s}^{c} n^{c}$. This defective spelling is noticed by I. Munro (1995a, 15, n. k) and also attested in TT 11 (see note l above).

$\mathrm{G}$ ) Omission of feminine ending - $t$ in the epithet of the goddess Neith ( $n b t S 3 w$ ), also attested in TT 11 and other sources (see note $m$ above).

H) For the special orthography of the name of Seth with the sign \, see comments by I. Munro 1988, 189.

I) $\quad w f 3$ and $j w f$ are the usual anatomical terms mentioned in the equivalence with the Lords of Kher-Aha (Munro 1988, 228). The defective writing - $w f w$ - of the Hanover manuscript might be owed to a mechanical confusion with the similar graphemes $w$ and 3 (I. Munro 1995a, 15, n. 1), or to the omission of the?

J) Cf. note s above.

K) The sign $\mathrm{S} 42$ resembles a sistrum. This orthography for the name of Sekhmet is not the most frequently used but is attested elsewhere (Hoenes 1976, 3-5).

L) This body limb is usually written in singular (cf. I. Munro 1994, 97, n. k). However, it is attested in dual in the manuscript of Baksu and other Eighteenth Dynasty examples and also quite often in plural (as in TT 11, see note $\mathrm{u}$ above).

M) Anomalous determinatives in the word mnty, differing from all known variants and resembling the signs in TT 11, especially in their upper half. See also note v above and the discussion below for a possible explanation.

N) Omission of genitival adjective $n$.

O) The snake determinative of $j^{c} r w t$ falls in a lacuna. The feminine concordance of ${ }^{c} n h w(t)$ is not written.
The Gliedervergottung section in TT 11 and pKM 1970.37 share the following seven significant features: number of identifications (18); body members and gods identified by means of adverbial statements; grammatical structure; orthographic patterns; common orthographic mistakes; special features in the spelling of certain words; and exactly the same divine determinatives (sharing their formal appearance and attributes, but differing in their stylistic and colourful/less rendering). These coinciding features will be examined before closing the section, highlighting some minor differences between the two sources.

Although opting for different layouts (list with one-register and table with two-registers), the two versions have in common the number, order, and nature of the identifications between body limbs and deities. The face $(h r)$ is not mentioned and the same body members ( $h t$ and $j 3 t$, mnty and ssty, and $\underline{d} b^{c} w$ and $s i h w$ ) are coupled with given gods. On the contrary, in other examples of the beginning to the mid- Eighteenth Dynasty these equivalences are unfolded in two identifications. Moreover, both instances are framed in the same tradition concerning the identifications fnd $\rightarrow$ Hnty- $\underline{h}$ s s, jbhw $\rightarrow$ Serket, and tbty $\rightarrow$ Ptah. Finally, both examples also share the use of the same toponym for the divinity linked to the nose, while two other contemporary traditions are attested (see notes $\mathrm{d}$ and $\mathrm{B}$ above). It should be also noted that Mendes in the name of the deity forming the eighth equation ( $b 3 n b \underline{D} d t)$ is spelled with a final $t$, while other manuscripts such as pParis Louvre N. 3074 or pCairo CG 40002 opt for writing Dtw.

A comparison among different contemporary manuscripts with BD 42 shows that several ways of building the adverbial sentences of identity were used to express the identifications between the two elements equated: Particle $+\mathrm{N}+$ indirect genitive $+\mathrm{NN}+m+\mathrm{GN}$ (i.e. $j w$ šny $n$ $W$ sjr NN $m N w n)$; Particle $+\mathrm{N}=$ suffix pronoun $+m+\mathrm{GN}$ (jw šny=j $m N w n$ ); N=suffix pronoun $+m+\mathrm{GN}$ (i.e. $\check{s} n y=j$ $m \mathrm{Nwn})$. Albeit the reasons for opting for one of these structures or combining several in one manuscript are not entirely clear - as stated by I. Munro ${ }^{46}$, the first version is attested in the two examples compared here.

In terms of orthography, the two witnesses display a very close spelling of nouns using mono and multiliteral signs accompanied by determinatives and not replacing

46 I. Munro 1995b, 19, n. h. In pParis Louvre E. 11085 both structures (with and without initial particle) alternate: 1.c., Photo-Pl. 19, col. 199-204. There is also no consensus in how these statements should be translated, whether as "the hair of Osiris NN is Nun" or "the hair of Osiris NN is that of Nun” (cf. Altenmüller 1977, 624-625 and DuQuesne 2002, 261, 263). 
pKM 1970.38, cols. 1-9 (BD 42)

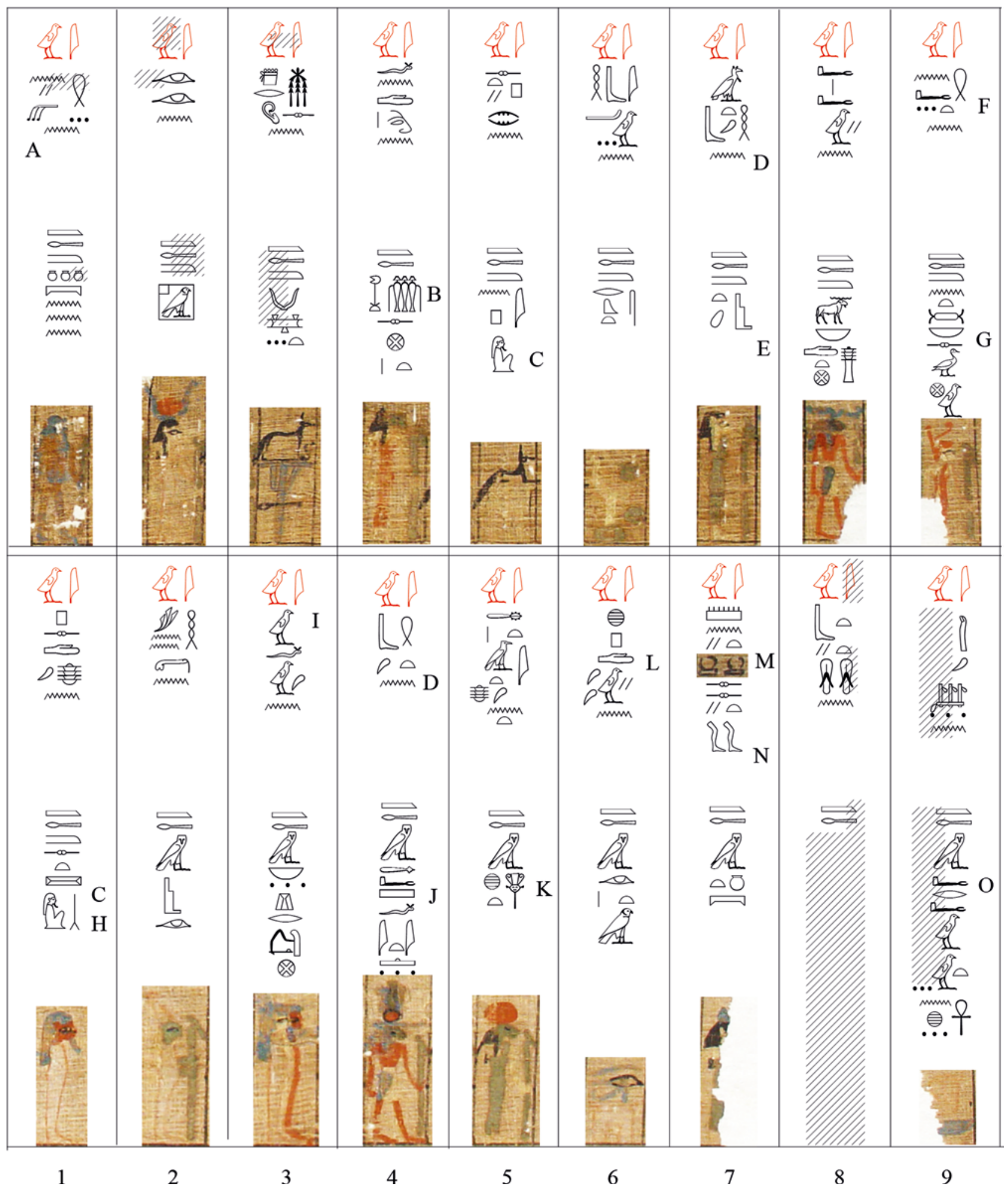

Figure 5: Transcription of the Gliedervergottung in BD 42 in pKM 1970.37. 
the former signs with logograms. As for misspellings and omissions, both versions share the superfluous plural strokes in $\check{s} n^{c}$ and the omission of the feminine ending in the epithet of Neith (Mistress of Sais) ${ }^{47}$. These features are found in other instances and would not justify in themselves the hypothesis that BD 42 in TT 11 and pKM 1970.37 derived from a common master copy. However, a combination of this observation with the rest of the similarities discussed in this section makes this hypothesis plausible. The most significant orthographic aspect is the spelling of the word mnty, with a dual determinative which - to my knowledge - is unattested in other witnesses of BD 42 (see notes $\mathrm{v}$ and $\mathrm{M}$ above and figure 7 ).

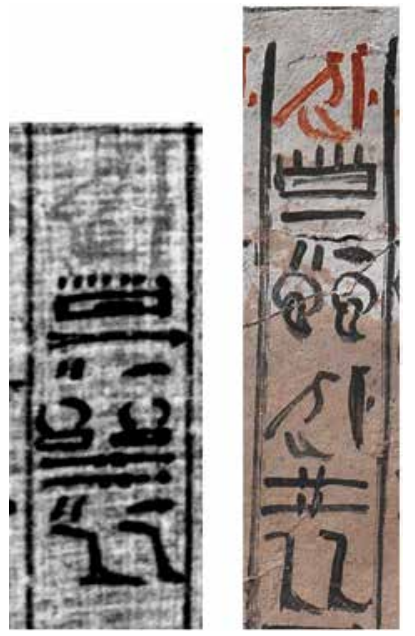

Figure 7: Spelling of the word mnty with unusual determinatives in pKM 1970.37 (left) and TT 11 (right). @ Djehuty Project and August Kestner-Museum, Hanover.

Despite the fact that the determinatives are not identical in shape in the two sources, the underlying grapheme seems to have been the same and was probably unfamiliar to the copyist of each version, who gave his personal rendering of the sign. More than an erroneous transcription, this case of shared curious spelling should be better regarded as the attempt of two copyists at faithful reproduction plus slight adaptation of an unfamiliar sign, initially written by the scribe who composed the model. Finally, both examples display a similar use of hieratic signs: G39 ( $\&$ ) in the toponym Sais (in columns 9 in TT 11 and 9, upper, in pKM 1970.37) and M2 (v) in the spelling of $h n n$ (respectively, in columns 11 and 2, lower). However, this similarity cannot be taken alone as proof of a common origin. On the one hand, these graphemes are among the most recurrent hieratic signs in BD documents written in cursive hiero-

47 See, respectively, notes $\mathrm{l}$ and $\mathrm{F}$ and $\mathrm{m}$ and $\mathrm{G}$ above. glyph ${ }^{48}$. On the other hand, the study of B. Lüscher on the ostraca used as Zwischenvorlage for remediating ${ }^{49}$ the funerary texts onto the walls of the tomb of Nakhtmin (TT 87) demonstrates that scribes could transcribe into cursive hieroglyphs signs - especially bird-related signs - that were written in hieratic in the model ${ }^{50}$.

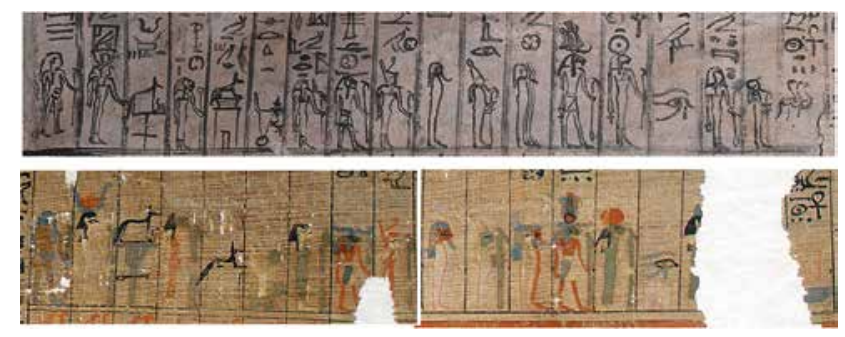

Figure 8: Detail of the enlarged divine determinatives in BD 42 on the ceiling of TT 11 (above) and on the scroll pKM 1970.37 (below). ( Djehuty Project and August Kestner-Museum, Hanover.

A direct comparison between the depictions of the divine determinatives at the bottom of each column (figure 8) shows that, despite opting for a different format (linear or one-register against tabulated or two-registers), they must have drawn on the same model. The same figures, in the same attitude, and sharing the same attributes (crowns, attire, and scepters) are depicted in black outlines (TT 11) and are polychromous (pKM 1970.37). Only the headdress of Nut seems to differ, lacking any distinguishing element in the former (but cf. n. i above for an alternative explanation) and displaying a $n w$-vase in the latter. Some of the gods of TT 11 (Serket, Isis, Sekhmet, ${ }^{3}$ s šfyt, and Nut) hold ankh-signs in their rear hands or in both pincers in the case of the former, whereas no emblem is depicted in the papyrus. The eye of Horus hovers in the air in TT 11, while it rests on top of a pavilion similar to the one used for the recumbent Anubis in pKM 1970.3751.

An evenness in content does not disguise notorious stylistic differences. The scribe or illustrator in charge of the papyrus displays a more confident hand, with figures'

48 I. Munro 1988, 254-257, Liste 19.

49 I follow Hussein (2017) in his definition of "remediation" as the transference of textual and pictorial materials from one medium of transcription to another. It is a process during which the materials undergo editorial alterations and can adopt different forms in their length, content, and written form. See section 4 below for examples of such alterations in the sources discussed in this article.

50 Lüscher 2013, 11, 30, 95-108.

51 Such marginal differences in documents deriving from the same source are not unusual and have been noted by I. Munro (2010, 205) when comparing the papyri of Tasheretenaset and pLondon BM EA 10558 and by Backes (2009, 95-97) when describing the papyri pBerlin P. 3158 and pAberdeen ABDUA 84023. 
neatly drawn and eyes notoriously large. This is not the case in TT 11, where, despite an elegant general outlook, a more hesitant or shaky hand is visible in the superposition of small strokes to create the outline of the divine figures and where many facial features are missing. Material aspects should come into play before making a judgment and one must bear in mind the technical difficulties inherent in the decoration of a ceiling. Besides, the person in charge of introducing the vignettes in the Hanover manuscript did not pay equal attention in the filling of goddesses' upper limbs. Most of the arms of these figures lack the yellow colour ${ }^{52}$, perhaps as a result of a hasty execution.

Notwithstanding general similarities, minor orthographic differences between the two documents under examination are attested. Although a similar use of phonetic complements can be observed in both, alternate options for rendering certain words are also discernible, often in cases involving an $s$ (with the two graphemic possibilities of the horizontal and the vertical signs $(\| /-\infty))$ : $m s \underline{d r}$, spty, Hnty-His, Srqt. Another case of graphic variant is perceptible for the preposition $m$ : while in TT 11 there is a general trend towards the owl-form (G17, ), pKM 1970.37 alternates - without apparent reason - between Aa15 $(\Longleftarrow$, only displayed in the upper registers of the table) and G17 (predominant in the lower registers). The degree of elaboration of a sign can differ: the simpler S42 ( (\}$)$ is rendered as a sistrum ( $\left(\begin{array}{l}\text { (T) } \\ \text { ) in }\end{array}\right)$ pHanover, while the scribe of TT 11 opted for a more detailed sign, anatomically closer to the sole of the feet ( $(9)$ instead of using the more common sandal (\$). The arrangement of orthographic components within a word also varies, with densely written square groups or space-saving options noticeably used in the manuscript of Baksu (cf. the sign distribution within words such as $\check{s}^{c}, m s \underline{d} r, j b h w, \underline{D} d t$, etc.). Furthermore, there are differences in number in the anatomical terms used, which can be recorded in singular or dual (ms $d r w y$ in TT 11 against $m s \underline{d r}$ in the Hanover papyrus) $)^{53}$ and differences in the rendition of the dual morpheme: double diagonal strokes and/or repetition of the determinative/ logogram. Such minor orthographic variations can be frequently recognised in other papyri deriving from the same master copy ${ }^{54}$, which were manufactured at a roughly con-

52 I owe this remark to Christian Loeben.

53 According to I. Munro 1994, 97, n. h) most of the versions of BD 42 opt for the dual rendering.

54 Lucarelli $(2006,245)$ concludes from the comparison of pCairo JE 95838 (Gatseshen, published by Lucarelli 2006) and pLondon BM EA 10064 (Paennestitawi, published by I. Munro 2001): "with the exception of some orthographical peculiarities and a somewhat different use of the rubrum in the opening formulas and in the divine names, the redaction of the spells is almost identical in the two papyri”. Cf. temporary time or with a difference of one generation ${ }^{55}$. It is highly significant that in cases where the template and the copy have been found, such tiny differences are also visible. The most conspicuous examples are those of the Duties of the Vizier (ostracon 292600 and walls of TT 29, the tomb of Amenemope) $)^{56}$ and the funerary texts of TT 87 (a whole collection of ostraca and walls of the burial chamber of Nakhtmin $)^{57}$.

The common features discussed in this section do not seem to be the product of a coincidence. On the contrary, it can be stated that behind the two witnesses, written on a layer of stucco coating the bedrock of a burial chamber ceiling and on a papyrus, lies a common master copy or Vorlage $e^{58}$. Differences in palaeography (specially the signs' ductus and module) and in style of the vignettes preclude the suggestion that the same scribal hand executed both versions. If the dating in the reign of Amenhotep II suggested by I. Munro for the papyrus in Hanover is accurate, this would even entail a one-generation separation between the two witnesses. Alternatively, and if a wider chronological framework also covering the reigns of Hatshepsut and Thutmose III (see section 1.2 above) is still retained, both examples would have made use of the same master copy at a roughly contemporary period. Be it as it may and with the difficulties entailed in dating funerary manuscripts, the use of the same Vorlage should not be

for the distinctive features of each exemplar: Lucarelli 2006, 17-21 and I. Munro 2001, 60. Despite the great similarity between pLondon BM EA 10793 (Pinedjem II: I. Munro 1996) and pLondon BM EA 10554 (Nestanebetisheru: Budge 1912), a close analysis of the two exemplars yields slight orthographic differences. Given the strong influence of Late Egyptian in their orthography, divergences are also noted in the addition/omission of divine determinatives and plural marks and in the use of the fillers $\bigodot, \Vdash, \triangle$ (I. Munro 1996, 48). The same is true of the papyrus of Tasheritenaset (Munro 2011) and pLondon BM EA 10558 (Ankhwahibre, http://totenbuch.awk.nrw.de/objekt/tm57267, last accessed 10.09.2016). A comparison of witnesses derived from the same model can be also found in Lüscher 2007, 35-40.

55 Copies of models or monuments undertaken centuries after the originals were produced will not be taken into account here, since processes of orthographic modernisation/archaisation and word-replacement might play a major role and generate greater differences. See examples provided in Hussein 2017, Der Manuelian 1994, and Kahl 2014, 164-165, 169.

56 Haring 2015, 70-71.

57 Lüscher 2013, 30 (detecting "geringfügige orthographische Unterschiede, leicht veränderte Zeichenstellungen oder seltene Fälle von Kopierfehlern" between the Vorlagen and the copy), 55-108.

58 The use of the same template for decorating papyri and burial chambers is also attested in the New Kingdom in Deir el-Medina (Lüscher 2007) and in the Third Intermediate Period (Lenzo in press, on the texts and images shared between the Theban pLondon BM EA 10554, the papyrus of Nestanebetisheru, and the Northern tombs of king Osorkon II (Tanis) and his son Sheshonq (Memphis)). 
taken as proof of contemporary production. As the studies of U. Rössler-Köhler on textual transmission of BD spells demonstrate, a given master copy could have remained in use over several generations and, through intermediary copies, even centuries ${ }^{59}$.

\section{Conclusion: Dublette, master copy, and scribal work}

The term dublette has been coined to describe copies derived from the same Vorlage, sometimes produced in the same workshop and in certain cases even by the same scribal hand. The word is applied when two or several papyri (or other media) share mainly internal features (omissions, additions, mistakes, deviating readings, sequence), and can also have external features (direction of writing, ductus, arrangement of signs, palaeography, colours in vignettes) in common ${ }^{60}$. Our two witnesses of the Gliedervergottung do not display similar external or formal features, except in the signs' orientation, probably as a result of the different media of transcription and mainly because different scribal hands/workshops were involved in their production. It is nonetheless remarkable that, if we don't take their whole textual sequence into account but examine only this section of BD 42, they coincide in practically all internal features. A similar concept to dublette, that of Textzwillinge, considers that two inscribed objects were based on the same Vorlage when they share orthographies (especially unusual ones), the same textual sections, important coincidences which cannot be otherwise explained by mistakes or fortuitous deviations, choice of vocabulary, omissions of paragraphs, additions of words, and the wording of some statements ${ }^{61}$. If these terms can be applied to individual sections of two witnesses, the Gliedervergottung of BD 42 in TT 11 and pKM 1970.37 represent instances of dublette or Textzwillinge.

The close examination of TT 11 and pKM 1970.37 leads to the conclusion that the same master copy was used to generate a small part of the decoration of the custom-made burial chamber of Djehuty and the pre-fabricated papyrus of Baksu ${ }^{62}$. It is important to state that although the same

59 Rössler-Köhler 1991, 1999.

60 Lüscher 2007, 40, 43 and 2015, 89, n. 25.

61 Sledzianowski 1975.

62 Parallels for a similar phenomenon can be found at Deir el-Medina during the Ramesside Period. The same master copy was used to decorate the (made-to-order) tombs of certain well-to-do inhabitants of the settlement and of pre-fabricated papyri (such as pNeuchâtel Eg. 429 and pPrinceton Pharaonic Roll 2, in which cases a name had model stood behind the two products compared here, it is at present impossible to determine which or how many intermediate steps marked the chain of textual remediation and transmission. An intermediate copy written on papyrus, leather, or ostraca (dubbed Zwischenvorlagen/ Handwerken-Vorlage or temporary media by different authors) could have been prepared from a template stored in a temple archive/library (probably the $p r-m \underline{d} 3 t$ ) or a workshop ${ }^{63}$. This intermediate carrier, rather than the valuable original, would have been later taken to the field in order to decorate the burial chamber of TT $11^{64}$. Regarding the papyrus in Hanover and following B. Backes, "it is difficult to envisage how decorated funerary papyri might have been produced without the existence of something akin to what would now be called a 'workshop"' ${ }^{65}$. But the relationship between centres of production and archiving of funerary composition (mainly temples) and those of production of funerary goods (workshops) are in need of further research, since it is still unknown how models circulated between both.

Once the existence of a common pattern has been demonstrated, one must draw attention to the analyses of Ramadan Hussein, according to whom the process of remediation (i.e. transference of materials from one medium of transcription to another $)^{66}$ was not a mechanical one and did not consist purely of copying. Instead, in the course of this process, editorial changes were introduced by the copyist with a direct impact on the length, content, and written form. The degree of intervention or freedom to act of a scribe over the composition to be remediated is difficult to assess in many instances but is undeniable ${ }^{67}$, and

not yet been inserted). See the study undertaken by Lüscher 2007. We should not jump to conclusions too quickly on wealth or status and type of crafted object. The famous papyrus of the chisel-bearer Neferrenpet (pBrussels MRAH 5043 + pPhiladelphia E 2775, 16720-2, Milde 1991) was made in advance in a Deir el-Medina workshop (Lüscher 2007) and then acquired by/for the owner of the tomb TT 336.

63 For different media in which Vorlage (either Archiv-Vorlagen or ad hoc hergestellte Vorlagen) could be recorded and used or stored, see Baines 2004, 28-30 and Lüscher 2015, 89-94.

64 Such a process, which entailed resorting to ostraca as intermediate models, can be followed in the case of the decoration of the burial chamber of Nakhtmin, Lüscher 2013, 10, 12-13, 25-28, 2015, 94-99. The same procedure would have been essayed in the decoration of some tomb statues, according to Gnirs 2016.

65 Backes 2010a, 2-3.

66 Hussein 2017, with recent bibliographical references to the nature of Vorlagen. See also note 49.

67 Several authors have stressed that in the process of textual transmission and edition, ancient Egyptian scribes - against the agents of transmission in so-called Religions of the Book - were not constrained by any rule of canonical reproduction of the models (Hornung 1992, 125; Rössler-Köhler 1991, 283-284; Vernus 1996, 161-162; 
it was probably marked by individual attitudes (with some scribes tending towards faithful reproduction ${ }^{68}$, whereas others consciously introduced more editorial changes), diachronic modifications (with periods in which the creativity of scribes was more exploited ${ }^{69}$ than others), the nature of the texts copied (with certain compositions more liable to "canonical reproduction" than others ${ }^{70}$ ), and also by material aspects (the physical traits of the surface and media to which the text is transferred).

The comparison between the two witnesses - the burial chamber and the papyrus - yields several examples of orthographic variation and highlights the flexibility of spellings in cursive hieroglyphic writing. Not in vain, the latter has been described as polyorthographic, i.e. a system in which multiple orthographies for a given word

Lucarelli 2006, 1-3; Lüscher 2015, 103). In fact, instances of dublette mentioned in $\mathrm{n} .51,54,58,69$, and 73 , and the example analysed here substantiate this statement.

68 The colophon closing the papyrus of Yuya (pCairo CG 51189: I. Munro 1994, Pl. 71, cols. 971-972) indicates that: jw=s pw $m$ hijt=s $r$ $p h w y=s(y) \quad m j$ gmyt $<m>s \check{s}, s p h r=t j, s h f t=t j, s m t r=t j, s m h \zeta=t(j) t j(t)$ $r(t) j(t)$, "it is finished from its beginning to its end as found $<\mathrm{in}>$ writing, being copied, collated, examined, and revised sign by sign". This formula more reflects the scribal attitude towards the faithful transmission of a composition than a common practice among New Kingdom copyists. For colophons in Egyptian literature, see Luiselli 2003 and Lenzo 2004, particularly in BD, see Lenzo 2004, 369-371. An outstanding example of a nearly identical reproduction of the offering formula of a Vorlage transferred onto three stelae is published by Marée (1993). Even the lines of text break off at the same points and the orthographical resemblances are striking (1993, 11-13). The three objects derive from the same sculptor, who did introduce minor orthographic variations in some cases, probably owing to the larger space available on one of the stelae $(1993,13)$. A fourth example attributed to the same sculptor displays a variation in the composition of the offering formula $(1993,16)$. Whether this change could be related to the use of a different Vorlage or to an individual adaptation of the model is not stated by the scholar.

69 Lucarelli underlines the freedom of the scribes in the adaptation of Vorlagen in the Third Intermediate Period (2006, 3, 237, 254), when an innovative process of textual patchwork marked by the collation and elaboration of earlier texts into new compositions took place (Lucarelli 2001-2002, 48-49). Backes (2009, 73-101) highlights the shared features and the widely divergent individual traits of three papyri produced in the same Theban workshop around 300 BC. If the same master copy underlies the vignettes of these manuscripts, "dann wäre die Freiheit bei der Übertragung auf den einzenlnen Papyrus sehr groß gewesen” $(2009,100)$.

70 von Lieven (2016) discusses the cases of the Amduat, Book of the Gates, Book of the Sky, Book of the Earth, Book of the Night, Book of the Day, and the Fundamentals of the Course of the Stars. The high degree of canonisation of these compositions contrasts with other corpora of texts subjected to open transmission, such as the Book of the Dead. could concurrently exist ${ }^{71}$. This flexibility results in the notation of words in a variety of options, which one may summarise in "extended" or "condensed" forms, especially where phonetic complements are involved or where purely logographic writings are chosen. Determinatives usually coincide in form and number between the two witnesses, although the papyrus opts for an extra semantic complementation with the sign A40 in two gods' names (see note $\mathrm{C}$ above). The selection of one option against other possibilities (extended or condensed forms, addition or omission of determinatives) depends on a variety of factors, among which the space availability played no small role. Space constraints are clear in pKM 1970.37, especially in the inner distribution of elements within long words inserted before the spaces left blank to add the owner's name, such as $m s \underline{d} r$ or $j 3 t$. Scribal habits and scribal training, with their local and diachronic changes, should be also taken into account when assessing orthographic variation among different sources ${ }^{72}$. But even among scribes of the same "school" and probably working in the same workshop, the same graphic variety is attested ${ }^{73}$. This visible orthographic flexibility supports the idea that a Book of the Dead spell is susceptible to change in the course of its transmission or reproduction, although whether the reasons behind the changes are intentional, unconscious (for example, through mental associations with similar concepts or with homophone or homonym words), or fortuitous is sometimes difficult to ascertain.

Do our two documents give us any hint about lost sources (i.e. the original template used) and scribal activities in the New Kingdom for the Book of the Dead production (i.e. the process of remediation)? Regarding the template, suggestions can be made concerning its possible layout or content distribution, writing system, colours used for the determinatives, and scope of the text.

71 Hussein (2017) complements explanations with a discussion on different views regarding ancient Egyptian scribal training and the orthographic system. The author draws attention to another important phenomenon which affected orthography: the importance of the overall design and of the visual aesthetics.

72 Sledzianowski 1975, 107.

73 An eloquent example is provided by the study of Backes (2009) of three closely related papyri: pBerlin P. 3158, pBerlin P. 3159, and pAberdeen ABDUA 84023. Texts copied from the same Vorlage on the three rolls (complete title, BD 30B, 72, 89, and 191) result in variants that share peculiar orthographic features, but differ in the use of extended or abbreviated forms of spellings and of place-filling signs as well as in the arrangement of graphemes within words and in the presence or absence of determinatives (2009, 31-43). The papyri are further orthographically linked by the uncommon use of an unetymological or "alphabetical" writing system (Backes 2009, 27-30, 2010a, 4-6). 
It is difficult to say how the layout of the Vorlage looked, if it displayed the identifications body limb $\rightarrow$ deity in one register (as in TT 11) or in two superimposed registers (as in pKM 1970.37). Given the even number of equations, it would not have been difficult for the copyist to arrange the contents in two registers if the columns were written one after the other in the model. Would the number has been uneven, the table-like distribution would have forced the scribe to look for creative solutions, unfolding or coupling identifications ${ }^{74}$, to obtain a balanced result. One could even venture that the master copy may have included indications of different possibilities for visually and spatially laying out the contents ${ }^{75}$, so that the scribe could opt for the solution that best fitted the material demands of the surface to be written on.

What about the script of the template? It is highly probable that the Vorlage (at least the temporary media used for copying the texts in TT 11) was written in cursive hieroglyphs. Recent analyses convincingly suggest that, at least in the case of tombs, "turning cursive drafts into hieroglyphic inscriptions on the spot - that is, in front of the wall - is unlikely, especially in narrow and poorly illuminated spaces, such as subterranean tomb chambers"76. Moreover, had the scribe/artist worked from a hieratic model, he would have had to face several problems when transforming every sign into its cursive hieroglyph equivalent, selecting even forms which lacked a graphemic equivalence in hieratic ${ }^{77}$. All this suggests that the model used in the tomb decoration would have been similar to the end product, in terms of writing system. Now, given that our two witnesses are so similar in orthography (spellings using the same phonetic complements and often the same determinatives, shared special orthographies and mistakes) and that "hieratic and hieroglyphic orthography follow different rules" likely also written in cursive hieroglyphs ${ }^{79}$. The occurrence

74 Mechanisms described by I. Munro 1988, 169.

75 Backes $(2009,12)$ suggests that master copies of Book of the Dead spells could have included titles or indications of their purpose that were not copied onto the final product intended for burial. Haring $(2015,80)$ indicates that Vorlage for decorating tomb walls may have included the texts to be copied on the surfaces and prescriptions for their graphic arrangement and vignettes. See also Kahl 2014, 167.

76 Haring 2015, 72, 74-79 (quotation is from p. 78). See also Lüscher 2015, 101-103 and, already, Kahl 1996, 70.

77 Haring 2015, 76-77. The latter is especially true for the sign Aa15, a flat sign contrasting with the hieratic form of Möller number 196. This flat $m$ is used in BD manuscripts written in cursive hieroglyphs, though less often than the owl.

78 Haring 2015, 78.

79 Baines $(2004,28)$ suggests that cursive hieroglyphs were more likely used than hieratic for significant archival copies of religious of hieratic signs on the papyrus roll in Hanover and on the ceiling of the burial chamber, noted in the previous section, should not be taken as proof of an original model written in hieratic that was transformed into cursive hieroglyphs in the final products. On the contrary, the use of these signs can be related either to the occasional presence of such forms in the Vorlage to be remediated (as the case of the ostraca used in TT 87 demonstrates) ${ }^{80}$ or to the background of scribal training. Since scribes learnt first to write in hieratic before moving into the hieroglyphic system at an advanced stage of their careers, it is no wonder that they reverted sporadically to their hieratic mechanised signs as they remediated a text written in cursive hieroglyphs. The latter change could happen mechanically and unconsciously, wittingly as a space saving solution (since hieratic signs generally occupy less space than the cursive ones), or for unknown reasons.

A doubtful issue is whether the vignette-like determinatives were rendered in the Vorlage in black outlines or in colour. The colour scheme used in pKM 1970.37 is the regular one for deities (blue and black for wigs, red for sun discs, white garments for mummy-like figures, multicoloured atef-crown) and would have been known to a trained "illuminator" if only the outlines were given in the model. A parallel situation to our only outlined vs polychrome figures is encountered in the Twenty-sixth Dynasty in the case of the Theban papyrus of Tasheretenaset and the Memphite product derived from the same model (pLondon BM EA 10558, of Ankhwahibre). While the former is polychrome, as other colourful Theban products of the same period, the latter gives only the black outlines and includes some details in red, in an attempt to match the local trends of the North ${ }^{81}$. This instance shows that the adoption of a Southern model in the North went hand in hand with adaptations in style and colour patterns. On the other hand, Textzwillinge derived from the same master-copy, and probably produced in the same workshop, could display slight variations in colour schemes ${ }^{82}$, so that

texts. On internal evidence, mainly the nature of scribe's misspellings, Allen argues that the original document from which the coffin B16C was decorated consisted of cursive hieroglyphs with some hieratic signs (1976, 26-27).

80 Such Zwischenvorlage on ostraca are written in cursive hieroglyphs, as are the texts on the walls of the burial chamber of Nakhtmin, but show some hieratic signs. Significantly, graphemes written in the latter system were often transcribed into cursive hieroglyphs by the scribe in charge of remediating the funerary compositions, the case of bird-signs being very prominent: Lüscher 2013, 11, 30 and comments to the synoptic edition 95-108, 2015, 103.

81 I. Munro 2010, 207.

82 Lüscher 2007, 16 (comparing the New Kingdom papyri pKaunas Tt-12848 and pBrussels E 5043 + pPhiladelphia E 2775, 16720-2). For 
the vignette painter need not have strictly adhered to the pattern of colours used in the template. They could also exhibit small differences in detail or in the degree of elaboration in the execution ${ }^{83}$. Such differences could explain the omission/addition of the ankh-signs in the enlarged determinatives of the deities in the two documents compared here, the more elaborate standard of Wepwawet in the Hanover manuscript, and the depiction of the pavilion as the pedestal for the Eye of Horus in the latter.

As for the extent of the master copy, it remains uncertain if the model preserved the whole chapter BD 42 or if it only comprised the Gliedervergottung section. Given that this is the only section shared by the burial chamber and the Hanover papyrus, the rest of the elements - title, introduction, sequel - could not be subjected to a comparison. On the other hand, there are examples on papyri ${ }^{84}$, tomb walls ${ }^{85}$, and coffins ${ }^{86}$ in which the Gliedervergottung was the only component of BD 42 reproduced, so the hypothesis that this section could be used and archived as a separate element, or taken as its most representative part, cannot be discarded.

Regarding copyists' activities in relation to the Book of the Dead, it is conspicuous that the iconographic repertoire of this section, centred upon the enlarged (quasi-vignette) determinatives of the deities, coincides practically in all details in the two examples under examination. This fact points to the faithful reproduction of the common model in what concerns the pictorial component. The mode of

slight variations in colours and details in the Judgment of the Dead in two Late Period papyri (pBerlin P. 3158 and pAberdeen ABDUA 84023) that drew on the same master copy for this scene, see Backes 2009, 95-97 and 2010a, 20, Fig. 1 and 2. Compare also the 36 shared vignettes in two papyri produced in the same workshop: pLondon BM EA 10064 (I. Munro 2001, 60-68; Lucarelli 2006, 244-245) and pCairo JE 95838 (Lucarelli 2006, 198-230). The latter must have drawn on the same model as pCairo JE 95879 and pCairo S.R. VII 11494 for the images (Lucarelli 2006, 243-244).

83 See works mentioned in the previous note and the detailed comparison between the vignettes of pTasheretenaset and pLondon BM EA 10558 in I. Munro 2011, 35-48.

84 pParis Louvre AE/N 3068 (Nebqed, temp. Thutmose IV-Thutmose IV/Amenhotep III, Devéria and Pierret 1872, Pl. XII), pLondon BM EA 10470 (Ani, Nineteenth Dynasty, Faulkner et al. 1994, Pl. 32), pLondon UC 71000 (Hepres, Hatshepsut/Thutmose III -Amenhotep II, the papyrus is in a fragmentary state, but only the Gliedervergottung seems to have been written: http://totenbuch.awk.nrw.de/objekt/tm134705, last accessed 10.09.2016).

85 TT 359 (Iniherkhau, Ramesses III-Ramesses IV, http://www.osirisnet.net/tombes/artisans/inerkhaou359/e_inerkhaou359_03.htm, last accessed 10.09.2016).

86 London BM EA 6693 (Itineb, Late Period, Taylor 2010, 178-179). The lid combines scenes of the deceased adoring different deities with the statements of the Gliedervergottung. production of each version is less clear and may well have differed from one source to another. In the case of TT 11, each column (text and enlarged determinative) was copied one after the other. Note a) above leaves no doubt that the determinatives were not written before the statements were introduced. In the manuscript of Hanover, it is not possible to say whether the determinatives were written before, after, or simultaneously to the text being copied. Someone with expertise in "illumination" could have even added them independently from the scribe, while in the case of TT 11 it is probable that the scribe who copied the texts executed these small "vignettes". The imprecise contours reflect the more "scribal" and less "artistic" hand of a copyist who felt less comfortable with figures' profiles that did not resemble his more familiar encyclopedia of written signs.

As for the written component and leaving aside the enlarged determinatives, whose treatment resembles more that of vignettes, a comparison between the two sources demonstrates that scribes were not constrained by the need for formal "canonical" reproduction. On the contrary, there was room for variation and individual choice, particularly in orthography, as long as the content (i.e. the poles of the equations) was respected. Scribes had to negotiate the advantages or constraints of their writing surface, and certain elements of their school training or even of their personal preferences could also influence the resulting product. On the other hand, the strong similarities discussed thus far also make it clear that the orthography of the model exerted an important influence on the final product and that this was closely followed in some parts of the decoration of the ceiling and the papyrus discussed. The result is a mixture of faithful and careful reproduction of the model with room for individual adaptations or alterations made in the spelling of the text.

The two witnesses under examination, the burial chamber of Djehuty and the papyrus of Baksu, have several spells in common: BD 25, 26, 28, 42, 99B, 102, and 125A. It is remarkable that only BD 102 shows such a close similarity in both sources as to suggest that they were based on the same model. The other formulae display great divergences and belong to different textual traditions. In archival terms, there was probably no copy of the tomb's decoration preserved and transmitted as a whole ${ }^{87}$, but a pool of versions of chapters stored (either by single chapters or by collections thereof, organised by topics for easier use and retrieval?) from which those in charge of

87 Cf. the case of integral copies of the texts decorating a wall or architectural part of some Siutian tombs (or their Vorlage) in sources from Thebes and Tebtunis (Kahl 1999, 268, 295-296). 
the decoration of a monument or an object could draw ${ }^{88}$. There are other cases attested in which two or more papyri/monuments share the same model copy for some spells or vignettes but not for all components: the Southern Hall of Offerings in the temple of Hatshepsut in Deir el-Bahari and the tomb of Puyemre (TT 39 ${ }^{89}$ ); pBerlin P. 3158, pBerlin P. 3159, and pAberdeen ABDUA $84023^{90}$.

In terms of textual transmission, this fact betrays the simultaneous circulation of different versions of a funerary composition in the same area. Moreover, there were probably no access restrictions to such a model, used both for a highly individualised monument of a top-rank official and for an object derived from a serial production and purchased by an individual of lesser status (or a member of his family).

Acknowledgements: This article is part of the Research Project HAR2014-52323-P, funded by the Spanish National Programme for Scientific Research, Technology, and Innovation. I would like to express my gratitude to Christian E. Loeben (Museum August Kestner, Hanover) for granting me permission to publish the section of papyrus Brocklehurst II discussed here and for providing me with information on this object. Thanks are also due to Barbara Lüscher (Ägyptologisches Seminar, Basel) for making available the colour image of this manuscript. Vincent Rondot and Marc Etienne (Department of Egyptian Antiquities, Louvre Museum) have kindly granted me the right to reproduce the image of pParis Louvre N. 3074, for which I am thankful.

88 According to Niwinski (1989, 23-25) the Theban Recension was based on small model-papyri comprising one long or several short spells sorted by thematic groups. Each workshop would have had a set of such model-papyri at its disposal. See also Lüscher 1998, 12, 97, who dubs the two options as Einzelsprüche-Vorlage and Teile-Vorlage. 89 The Offering List in both monuments incorporated CT 607 and several PT. While the PT spells of TT 39 are identical with those of the Chapel of Hatshepsut, CT 607 was copied from another source: Stupko-Lubczyńska 2013, 654-655.

90 See the analysis by Backes 2009, 2010a. The similarities among these papyri and their individual traits lead the scholar to suggest an "Szenario einer kleinen werkstatteigenen Sammlung von Vorlagen für Texte und Vignetten, aus der man für jeden Papyrus sozusagen „à la carte“ ein individuelles Programm zusammenstellen konnte” (2010b, 104).

\section{Bibliography}

Altenmüller, H., 1977, LÄ II, 624-627, 1977, s. v. “Gliedervergottung".

Allen, J. P., 1976, "The funerary Texts of King Wahkare Akhtoy on a Middle Kingdom Coffin”, in: J. H. Johnson, E. F. Wente (eds.), Studies in Honor of George R. Hughes. SAOC 39, 1-29.

Assmann, J., Bommas, M., 2002, Altägyptische Totenliturgien, Band 1. Totenliturgien in den Sargtexten des Mittleren Reiches. Supplemente zu den Inschriften der Heidelberger Akademie der Wissenschaften Philosophischen-historische Klasse 14.

Backes, B., 2009, Drei Totenpapyri aus einer thebanischen Werkstatt Der Spätzeit (pBerlin P. 3158, pBerlin P. 3159, pAberdeen ABDUA 84023). HAT 11.

- 2010a, "Three funerary papyri from Thebes: New evidence on scribal and funerary practice in the Late Period", BMSAES 15, $1-21$.

- 2010b, “Das Massaker von Herakleopolis. Ein Beitrag zum Buch der Himmelskuh und Totenbuch-Spruch 42", in: H. Knuf, C. Leitz, D. Von Recklinghausen (eds.), Honi soit qui mal y pense. Studien zum pharaonischen, griechisch-römischen und spätantiken Ägypten zu Ehren von Heinz-Josef Thissen. OLA 194, 15-23.

Backes, B., et al. 2009, Bibliographie zum Altägyptischen Totenbuch. SAT 13.

Baines, J., 2004, "Modelling Sources, Processes, and Locations of Early Mortuary Texts", in: S. Bickel, B. Mathieu (eds.), D'un monde à l'autre, Textes des Pyramides et Textes des Sarcophages. Actes de la Table Ronde Internationale. BiÉtud 139, 15-41.

Budge, E. A. W., 1912, The Greenfield Papyrus in the British Museum. The funerary Papyrus of Princess Nesitanebtashru, Daughter of Painetchem II and Nesi-Khensu, and Priestess of Amen-Ra at Thebes, about B.C. 970.

David, R., 1980, The Macclesfield Collection of Egyptian Antiquities, with a foreword of the late C.D.F.P. Brocklehurst.

Deicher, S., Maroko, E., (eds.), 2015, Die Liste. Ordnungen von Dingen und Menschen in Ägypten. Ancient Egyptian Design, Contemporary Design History and Anthropology of Design 1.

Devéria, Th., Pierret, P., 1872, Le papyrys de Nebqed, exemplaire hiéroglyphique du Livre des Morts.

Dewachter, M., 1982, review of David, R. 1980, The Macclesfield Collection of Egyptian Antiquities, with a foreword of the late C.D.F.P. Brocklehurst, Bibliotheca Orientalis XXXIX, № 5-6, 551-558.

Díaz-Iglesias Llanos, L., 2014, El ciclo mítico de Heracleópolis Magna. Continuidad y reelaboración a partir de las fuentes funerarias y cultuales. AulaÆEgyptiaca Studia 7.

- 2017, "The Book of Going Forth by Day in the funerary chamber of Djehuty (TT 11): past, present, and future”, in: G. Rosati, M. C. Guidotti (eds.), Proceedings of the XI International Congress of Egyptologists, Florence, Italy 23-30 August 2015. Archaeopress Egyptology 19, 177-183.

Diego Espinel, A., 2014, “Play and display in Egyptian High Culture: the Cryptographic texts of Djehuty (TT 11) and their sociocultural context”, in: J. M. Galán, B. M. Bryan, and P. F. Dorman (eds.), Creativity and Innovation in the Reign of Hatshepsut. SAOC 69, 297-335. 
Dodson, I., 1998, "On the Burial of Maihirpri and certain coffins of the Eighteenth Dynasty”, in: C. J. Eyre (ed.), Proceedings of the Seventh International Congress of Egyptologists, Cambridge, 3-9 September 1995. OLA 82, 331-338.

DuQuesne, T., 2002, “La déification des parties du corps. Correspondances magiques et identification avec les dieux dans l'Égypte ancienne", in: I. Koenig (ed.), La Magie en Égypte: à la recherche d'une définition. Actes du colloque organisé par le Musée du Louvre les 29 et 30 septembre 2000, 239-271.

Faulkner, R. O. et al., 1994, The Egyptian Book of the dead: the Book of going forth by day: being the Papyrus of Ani (royal scribe of the divine offerings), written and illustrated circa 1250 B.C.E., by scribes and artists unknown, including the balance of chapters of the books of the dead known as the Theban recension, compiled from ancient texts, dating back to the roots of Egyptian civilization.

Galán, J. M., 2009, “Early Investigations in the Tomb-chapel of Djehuty (TT 11)”, in: D. Magee, J. Bourriau, S. Quirke (eds.), Sitting beside Lepsius: Studies in Honour of Jaromir Malek at the Griffith Institute. OLA 185, 155-181.

Galán Allué, J. M., 2012, “El Descubrimiento de la Cámara Sepulcral de la Tumba-Capilla de Djehuty (TT 11)”, in: L. M. de Araújo, J. das Candeias Sales (eds.), Novos trabalhos de Egiptologia Ibérica: IV Congresso Ibérico de Egiptologia, I, 413-432.

Galán, J. M., 2013a, "Nut on the ceiling of the Burial Chamber of Djehuty (TT 11)”, in: E. Frood, A. McDonald (eds.), Decorum and Experience: Essays in ancient Culture for John Baines, 119-126.

- 2013b, "The Book of the Dead in the Burial Chamber of Djehuty (TT 11)”, Egyptian Archaeology 42, 21-24.

- 2014, "The Inscribed Burial Chamber of Djehuty (TT 11)", in: J. M. Galán, B. M. Bryan, P. F. Dorman (eds.), Creativity and Innovation in the Reign of Hatshepsut. SAOC 69, 247-272.

Gnirs, A., 2016, “Ein Hymnus in unerwartetem Kontext”, in: Ph. Collombert, D. Lefèvre, S. Polis, J. Winand (eds.), Aere Perennius, Mélanges égyptologiques en l'honneur de Pascal Vernus. OLA 242, 253-302.

Haring, B. B., 2015, “Hieratic Drafts for Hieroglyphic Texts?”, in: U. Verhoeven (ed.), Ägyptologische»Binsen»-Weisheiten I-II. Neue Forschungen und Methoden der Hieratistik. Akten zweier Tagungen in Mainz im April 2011 und März 2013, 67-84.

Hoenes, S. E., 1976, Untersuchungen zu Wesen und Kult der Göttin Sachmet.

Hoffmann, F., 2015, “Aufzählungen, Listen, Katalogue und Tabelle im alten Ägypten - formale und inhaltliche Aspekte”, in: S. Deicher, E. Maroko (eds.), Die Liste. Ordnungen von Dingen und Menschen in Ägypten. Ancient Egyptian Design, Contemporary Design History and Anthropology of Design 1, 87-123.

Hornung, E., 1992, “Zur Struktur des ägyptischen Jenseitsglauben”, ZÄS 119, 124-130.

Hussein, R., 2017, “Text Transmission or Text Reproduction? The Shifting Materiality of Pyramid Texts Spell 267, in: S. Bickel and L. Diaz-Iglesias (eds.), Studies in Ancient Funerary Literature. OLA 257, 295-329.

Kahl, J., 1996, Steh auf, gib Horus deine Hand. Die Überlieferungsgeschichte von Altenmüllers Pyramidentext-Spruchfolge D. GOF $\mathrm{IV} / 32$.

- 1999, Siut-Theben. Zur Wertschätzung von Traditionen im alten Ägypten. ProblAeg 13.
- 2014, “Assiut - Theben - Tebtynis. Wissensbewegungen von der Ersten Zwischenzeit und dem Mittleren Reich bis in Römische Zeit", SAK 43, 159-172.

Lapp, G., 1997, The papyrus of Nu. Catalogue of the Books of the Dead in the British Museum 1.

- 2017, Die Feindabwehrsprüche (Tb 31-37, 39-42). Tbt 10.

Lenzo, G., 2004, "Les colophons dans la littérature égyptienne", BIFAO 104, 359-376.

- in press, “Textes funéraires de la Troisième Période intermédiaire dans divers contextes : le P. Nedjemet (P. BM EA 10490), le P. Greenfield (P. BM EA 10554) et le chapitre 23 du Livre des Morts”, in: J. F. Quack, D. C. Luft (eds), Schrift und Material. Praktische Verwendung religiöser Text- und Bildträger als Artefakte im alten Ägypten, Tagungsband zum internationalen IWH-Symposium „Praktische Verwendung religiöser Artefakte (Text-/Bildträger)“, Heidelberg. ORA.

von Lieven, A., 2016, “Closed canon vs Creative Chaos. An indepth Look at (Real and Supposed) Mortuary Texts from Ancient Egypt”, in: K. Ryholt and G. Barjamovic (eds.), Problems of Canonicity and Identity Formation in Ancient Egypt and Mesopotamia. CNI Publications 43, 51-78.

Lucarelli, R., 2001-2002, “Ch. 41 of the Book of the Dead”, JEOL 37, 41-50.

- 2006, The Book of the Dead of Gatseshen: ancient Egyptian funerary religion in the 10th century BC. EgUit 21.

Luft, U., 1977, “Das Totenbuch des Ptahmose. Papyrus Kraków MNK IX-752/1-4”, ZÄS 104, 46-75.

Luiselli, M. M., 2003, "The Colophons as an Indication of the Attitudes towards the Literary Tradition in Egypt and Mesopotamia”, in: S. Bickel and A. Loprieno (eds.), Basel Egyptology Prize 1. Junior Research in Egyptian History, Archaeology and Philology. AH 17, 343-360.

Lüscher, B., 1998, Untersuchungen zu Totenbuch Spruch 151. SAT 2.

- 2007, Totenbuch-Papyrus Neuchâtel Eg. 429 und Princeton Pharaonic Roll 2. Zur Totenbuch-Tradition von Deir el-Medina. BAÄ 1.

- 2013, Die Vorlagen-Ostraka aus dem Grab des Nachtmin (TT 87). BAÄ 4.

- 2015, “Kursivhieroglyphische Ostraka als Textvorlagen: Der (Glück-)Fall TT 87”, in: U. Verhoeven (ed.), Ägyptologische "Binsen"-Weisheiten I-II. Neue Forschungen und Methoden der Hieratistik. Akten zweier Tagungen in Mainz im April 2011 und März 2013, 85-117.

Der Manuelian, P., 1994, Living in the Past. Studies in Archaism of the Egyptian Twenty-sixth Dynasty. Studies in Egyptology.

Marée, M., 1993, “A Remarkable Group of Egyptian Stelae from the Second Intermediate Period", OMRO 73, 7-22.

Massart, A., 1959, “À propos des "listes” dans les texts égyptiens funéraires et magiques", Studia biblica et orientalia III, 227-245.

Mauric-Barberio, F., 2003, “Copie de textes à l'envers dans les tombes royale”, in: G. Andreu (dir.), Deir el-Médineh et la Vallée des Rois. La vie en Égypte au temps des pharaons du Nouvel Empire, 173-194.

Milde, H., 1991, The Vignettes in the Book of the Dead of Neferrenpet. EgUit 7.

Munro, I., 1988, Untersuchungen zu den Totenbuch-Papyri der 18. Dynastie: Kriterien ihrer Datierung. Studies in Egyptology.

- 1994, Die Totenbuch-Handschriften der 18. Dynastie im Ägyptischen Museum Cairo. ÄA 54. 
- 1995a, Das Totenbuch des Bak-sw (pKM 1970.37/pBrocklehurst) aus der Zeit Amenophis' II. HAT 2.

- 1995b, Das Totenbuch des Jah-mes (pLouvre E. 11085) aus der frühen 18. Dynastie. HAT 1.

- 1996, Der Totenbuch-Papyrus des Hohenpriesters Pa-nedjem II (pLondon BM 10793). HAT 3.

- 2001, Das Totenbuch des Pa-en-nesti-taui aus der Regierungszeit des Amenemope (pLondon BM 10064). HAT 7.

- 2010, "Evidence of a master copy transferred from Thebes to the Memphis area in Dynasty 26", BMSAES 15, 201-224.

- 2011, Die Totenbuch-Papyri des Ehepaars Ta-scheret-en-Aset und Djed-Chi aus der Bes-en-Mut Familie (26. Dynstie, Zeit des Königs Amasis). HAT 12.

Munro, P., 1970, Brocklehurst-Papyrus im Kestner-Museum, Hanover.

- 1973, “Kestner-Museum Jahresbericht 1970-1973”, Hannoversche Geschichtsblätter Neue Folge 27, Heft 3/4, 303-355.

Naville, E., 1886, Das aegyptische Todtenbuch der XVIII. bis XX. Dynastie.

Niwinski, A., 1989, Studies on the illustrated Theban funerary papyri of the 11th and 10th centuries B.C. OBO 86.

Quirke, S., 2013, Going out in Daylight - prt m hrw - the Ancient Egyptian Book of the Dead: translation, sources, meanings. GHP 20.

Ragazzoli, Ch., 2010, "The Book of the Dead of Ankhesenaset (P. BNF Egyptien 62-88). Traces of workshop production or scribal experiments?”, BMSAES 15, 225-248.

Ranke, H., 1924, "Die Vergottung der Glieder des menschlichen Körpers bei den Ägyptern”, OLZ 27, 558-564.

Ratié, S., 1968, Le papyrus de Neferoubenef (Louvre III 93). BiÉtud 43.

Rössler-Köhler, U., 1991, “Bemerkungen zur Totenbuch-Tradierung während des Neuen Reiches und bis Spätzeitbeginn, in U. Verhoeven and E. Graefe (eds.), Religion und Philosophie im Alten Ägypten. Festgabe für Philippe Derchain zu seinem 65. Geburtstag am 24 Juli 1991. OLA 39, 277-291.
- 1999, Zur Tradierungsgeschichte des Totenbuches zwischen der 17. und 22. Dynastie (Tb 17). SAT 3.

Serrano, J. M., 2014, "The Composition of the Opening of the Mouth in the Tomb-chapel of Djehuty (TT 11)", in: J. M. Galán, B. M. Bryan, and P. F. Dorman (eds.), Creativity and Innovation in the Reign of Hatshepsut. SAOC 69, 273-295.

Sledzianowski, B., 1975, “Miszelle über Textzwillinge”, in W. Westendorf (ed.), Göttinger Totenbuchstudien: Beiträge zum 17. Kapitel. GOF IV/3, 107-114.

Spieser, C., 2001, "Serket, Protectrice des enfants à naître et des défunts à renaître”, RdE 52, 251-264.

- 2006, "Nouvelles approches de l'image emblematique de Serket: le serpent, la corne et l'uterus", GM 209, 91-99.

Stupko-Lubczyńska, A., 2013, "The Chapel of Hatshepsut as an Inspiration for the Theban Tombs Decoration. The Case of TT 39 (Puyemre)", Études et Travaux XXVI, 654-662, Pl. 1-8.

Tarasenko, N., 2009, "The BD 42 Vignettes during the New Kingdom and Third Intermediate Period”, in: B. Backes, M. Müller-Roth, and S. Stöhr (eds.), Ausgestattet mit den Schriften des Thot: Festschrift für Irmtraut Munro zu ihrem 65. Geburtstag. SAT 14, 239-265.

- 2013, “Development of illustrative tradition of the chapter 42 of the Book of the Dead", SAK 42, 325-348.

Tawfik, T. S., 2008, 2018. Die Vignette zu Totenbuch-Kapitel 1 und vergleichbare Darstellungen in Gräbern. PhD Dissertation Bonn.

Taylor, J. (ed.), 2010, Journey through the Afterlife. Ancient Egyptian Book of the Dead.

Verhoeven, U., 1999, Das Totenbuch des Monthpriesters Nespasefy aus der Zeit Psammetichs I: pKairo JE 95714 + pAlbany 1900.3.1, pKairo JE 95649, pMarseille 91/2/1 (ehem. Slg. Brunner) + pMarseille 291. HAT 5.

Vernus, P., 1996, “La position linguistique des Textes des sarcophages", in: H. Willems (ed.), The World of the Coffin Texts, Proceedings of the Symposium held on the Occasion of the 100th Birthday of Adriaan de Buck, Leiden, December 17-19, 1992. EgUit 9, 143-196. 